\title{
COMMENTS
}

\section{BETAMAX AND INFRINGEMENT OF TELEVISION COPYRIGHT}

\section{INTRODUCTION}

A case pending in Federal District Court in the Central District of California ${ }^{1}$ will decide whether "vidiots,", persons recording copyrighted television shows on recording machines attached to their television sets at home, infringe the copyrights of those shows. The plaintiffs are Universal City Studios, Inc. and Walt Disney Productions, owners of copyrighted television shows. The defendants are Sony Corporation, Sony Corporation of America, several retail stores and an individual: makers, distributors, sellers and users of "Betamax," Sony's color video recorder. ${ }^{3}$ The basic allegation ${ }^{4}$ is that use of Betamax-in home and in store demonstrations-

THE FOLLOWING CITATIONS WILL BE USED IN THIS COMMENT:

Pre-Trial Memorandum for Plaintiff, Universal City Studios, Inc. v. Sony Corp. of America, 429 F. Supp. 407 (C.D. Cal. 1977) [hereinafter cited as Pre-Trial Memorandum for Plaintiff];

Pre-Trial Memorandum for Defendant, Universal City Studios, Inc. v. Sony Corp. of America, 429 F. Supp. 407 (C.D. Cal. I977) thereinafter cited as Pre-Trial Memorandum for Defendant];

U.S. Copyright Office, Second Supplementary Report of the Register of Copyrights on the General Revision of the Copyright Law: 1975 Revision Bill (Oct.-Dec. 1975) (unpublished report prepared for use of Congress in considering the Revision Bill) thereinafter cited as Second Supplementary Report];

H.R. REP. NO. 1476, 94th Cong., 2d Sess. 1, reprinted in [1976] U.S. CODE CONG. \& AD. News 5659 [hereinafter cited as H.R. ReP. No. 1476];

H.R. REP. No. 487, 92d Cong., 2d Sess. I, reprinted in [1971] U.S. CODE CONG. \& AD. News 1566 [hereinafter cited as H.R. REP. No. 487].

1. See Universal City Studios, Inc. v. Sony Corp. of America, 429 F. Supp. 407 (C.D. Cal. 1977).

2. Fong-Torres, Freedom of Video: The Battle Begins at Home, Rolling Stone, Sept. 8, 1977 , at 59 , col. 2.

3. Though earlier generation models carried a caveat against using it to record copyrighted material, Pre-Trial Memorandum for Plaintiff at 4, Betamax is marketed without any reference to potential copyright infringements.

4. It was also alleged that defendant's actions constitute unfair competition and intentional inference with contractual and prospective business advantage. Pre-Trial Memorandum for Plaintiff at 93-I07.

However, in Universal City Studios, Inc. v. Sony Corp. of America, 429 F. Supp. 407 (C.D. Cal. 1977), the District Court granted defendants' motion to dismiss for failure to state a claim under the Lanham Trade-Mark Act, I5 U.S.C. § 1125(c) (1970). Plaintiffs opposed the 
infringes plaintiffs' copyrights under 17 U.S.C. $\S \S 1(a), 1(d),{ }^{5}$ and that such use will also infringe the new copyright act, ${ }^{6} 17$ U.S.C. $\$ 106(1)$, which became effective January $1,1978 .^{7}$

The selling of videotape recorders is a very new, ${ }^{8}$ rapidly growing business. ${ }^{9}$ Universal would like to nip this growth in the bud because it portends loss of income both from reduced value of re-runs ${ }^{10}$ and from competition that is sure to come from videotape pirates ${ }^{11}$ who will increase in number with increased accessibility of videotape recorders. On the other

motion to dismiss this noncopyright claim with two arguments. First, certain statements in advertisements implied that the recording was with Universal's consent and that the recording was legal. The test for liability was then whether sufficient public confusion was caused as to the legality of using Betamax. The court rejected this line of reasoning on three grounds. Section 1125(a) requires a false representation of source or origin, and consent is not such a representation. Further, the public confusion test is much more appropriate in 15 U.S.C. $\$ 1114$ (1970), which has language to that effect while section 1125(a) does not. Finally, even if the public confusion test were used, Universal faced an impossible burden of proof in distinguishing public confusion caused by Sony's advertising from a general preconceived notion that goods sold on the open market have a legal use.

Second, Universal argued that Sony's failure to disclose to the public the possible legal consequences of using Betamax was itself actionable. Universal relied on three recent cases that required an advertiser to make additional statements to escape liability under section 1125(a): Gilliam v. American Broadcasting Co., 538 F.2d 14 (2d Cir. 1976); CBS, Inc. v. Gusto Records, Inc., 403 F. Supp. 447 (M.D. Tenn. 1974); Skil Corp. v. Rockwell Int'l Corp., 375 F. Supp. 777 (N.D. Ill. 1974). The court distinguished these cases from the Betamax case in a twostep process. It noted that the above cases all required the creation of a false impression and that none was created here. After all, the legality of Betamax is the question of the suit; any implied legality may be truthful. Further, Sony was under no obligation to dispel pre-existing, possibly erroneous ideas. Finally, a failure to disclose is neither "false" nor a "misrepresentation" as required by section $1125(\mathrm{a})$.

5. \$1. Any person entitled thereto ... shall have the exclusive right:

(a) To print, reprint, publish, copy and vend the copyrighted work; . . .

(d).

(d) . . . to exhibit, perform, represent, produce or reproduce it in any manner

or by any method whatsoever ....

17 U.S.C. $\S \S 1(a),(d)(1970)$.

6. The new Act is significant for any prospective relief since all causes of action arising on or after January 1, 1978 arise under the new Act. Pub. L. No. 94-553, $\$ 112$ in note to 17 U.S.C.A. $\S 501$ (West 1977).

7. "[T]he owner of copyright . . . has the exclusive rights . . .

(1) to reproduce the copyrighted work in copies or phonorecords . . . ."

17 U.S.C.A. § 106(1) (West 1977).

8. Pre-Trial Memorandum for Plaintiff at 2. See note 3 supra.

9. See Wall St. J., Sept. 26, 1977, at 10, col. 3. Sony has already sold over 100,000

Betamax units. Id. See also Newsweek, Oct. 31, 1977, at 70, col. 3.

10. Meyer, TV Cassettes-A New Frontier for Pioneers and Pirates, 19 BuLL. Cr. Soc. 16, 38 (1971-72).

11. See United States v. Atherton, 561 F.2d 747 (9th Cir. 1977); United States v. Drebin, 557 F.2d 1316 (9th Cir. 1977); United States v. Wise, 550 F.2d 1180 (9th Cir.), cert. denied, 98 S. Ct. 416 (1977) (pirates dealing in stolen and copied movie films); Wall St. J., March 2, 1978 at 1, col. 6 , and at 40 , col. 5 . 
hand, Sony would like to exploit the new market, ${ }^{12}$ and the home user would like to enjoy the "freedom" of memorializing whatever appears on his television set.

The principal question to be decided is whether a home user, acting without intent to profit, may record copyrighted television shows without infringing the copyrights. ${ }^{13}$ A negative answer would result in contributory liability for the makers, distributors and sellers of Betamax. ${ }^{14}$ Possible indirect results of the litigation would be the shut-down of a new, vigorous industry ${ }^{15}$ or the reworking of the licensing and profit structure of the television industry. Thus, the potential economic impact of the decision is significant. The purpose of this Comment is to explore whether such limited in-home copying, done without an intent to profit, infringes television show copyrights. Recent developments in the right of public performance of a copyrighted work and in the right of copying sound recordings will be analyzed. In addition, this Comment will examine a newly-emerging corollary to the equitable doctrine of fair use, the "home use exception." Although the arguments on both sides of this close question will be presented, it will be concluded that non-commerical, home recording of copyrighted televison programs is not an infringement.

12. Sony, of course, has competition in the new market. See Newsweek, Oct. 31, 1977, at 69 , col. 1. This competition is driving the price of recorders down. Wall St. J., Sept. 26, 1977, at 10 , col. 3.

13. A corollary question is whether store demonstrations of Betamax in which copyrighted material is recorded infringe the copyrights of the material. This is not, however, as serious a problem as home recording, since it can be eliminated without significantly damaging the industry.

14. See notes 28-31 infra and accompanying text.

15. It is difficult to imagine what form the injunctive relief would take, since not all television shows are copyrighted. Injunctions are usually granted to prevent only an unlawful use. Simmons Hardware Co. v. Waibel, 1 S.D. 488, 47 N.W. 814 (1891) (South Dakota Supreme Court sustained an ex parte injunction requiring the defendant to give to a court receiver his unlawfully obtained copy of plaintiff's secret pricing code); 18 AM. JUR. 2D Copyright and Literary Property § 131 (1965). 17 U.S.C. \& 2 (1970) (old act) clearly provides for injunctive relief. 17 U.S.C.A. $\$ 502$ (West 1977) (new act) will permit issuance of injunctions "on such terms as . . . [the court] may deem reasonable to prevent or restrain copying of a copyright." Although arguably unreasonable because it would restrain copying of noncopyrighted shows, one approach could be simply to bar the sale of audiovisual recorders. Another approach could be to require, if technologically feasible, that a mechanism be placed in the recorders to prevent them from recording copyrighted shows. Because it determined that in-home recording of copyrighted records infringed their copyrights in the records, the First Civil Senate of the Federal Supreme Court of Western Germany in GEMA v. Grundig G.m.b.H., 17 B.G.H.Z. 266 (1955), granted injunctive relief requiring the manufacturer to place notices on its tape recorders that it was illegal to use them to record copyrighted materials. This rather hollow victory for the plaintiffs was bolstered legislatively by the establishment of a compulsory license mechanism that required the purchaser of a tape recorder to pay a fee to copyright owners at the time of purchase. 51 B.G.B. 1, 1273, § VI, art. 53(5), reprinted in UNESCO LAWS AND TREATISES OF the World on the Protection of Performers, Producers of Phonograms and BroadCastING ORGANIZATIONS (1969). 


\section{THE ELEMENTS OF LIABILITY}

Assuming that the merits of the claims are reached, ${ }^{16}$ and absent establishment of an equitable defense, ${ }^{17}$ plaintiffs have a very strong case for infringement. The law of copyright gives persons a protected property interest in the expression of ideas, but not in the ideas themselves. ${ }^{18}$ To establish infringement, a plaintiff must prove ownership of the copyright and copying ${ }^{19}$ by the defendant. ${ }^{20}$ One commentator has articulated the

16. It is quite possible, however, that the issue of infringement will not be litigated in this case. There is serious question whether the key defendant-Griffith, the home user-and plaintiffs are engaging in a collusive suit which should be dismissed for want of adverse parties. See Coffman v. Breeze Corp., 323 U.S. 316, 324 (1945) (a complaint by a patent owner against licensees seeking to have a congressional act declared unconstitutional but seeking no relief from defendants dismissed for want of adversity); United States v. Johnson, 319 U.S. 302,305 (1943) (suit by a tenant against landlord for violation of rent control dismissed as collusive "friendly suit" brought at request of defendant); Muskrat v. United States, 219 U.S. 346,357 (1911) (case or controversy requires adverse parties). Through discovery, the corporate defendants have determined that Griffith has retained plaintiffs' law firm several times, that the plaintiffs' attorneys consider him a nominal defendant and have agreed to waive any damages against him, that Griffith is indifferent to the outcome of the case and has never intended to retain counsel to represent him and that Griffith is being sued with his permission. Pre-Trial Memorandum for Defendant at 66. See generally id. at 65-69. These allegations, if true, indicate that the District Court lacks jurisdiction. 28 U.S.C. § 1359 (1970) ("A district court shall not have jurisdiction of a civil action in which any party . . . has been improperly or collusively . . . joined"). At any rate, dismissal might be appropriate because of no "honest and actual antagonistic assertion of rights . . . " United States v. Johnson, 319 U.S. 302, 305 (1943); accord, Chicago G.J.R. v. Wellman, 149 U.S. 339 (1892); Lord v. Veazie, 49 U.S. (8 How.) 251 (1849).

17. See notes $145-88$ infra and accompanying text.

18. Mazer v. Stein, 347 U.S. 201, 217 (1954); White-Smith Music Pub. Co. v. Apollo Co., 209 U.S. 1, 19 (1907) (Holmes, J., concurring specially); Rokeach v. Avco Embassy Pictures Corp., No. $75-49$ (S.D.N.Y. Jan. 18, 1978).

19. Jeweler's Circular Pub. Co. v. Keystone Pub. Co., 281 F. 83, 94-95 (2d Cir.), cert. denied, 259 U.S. 581 (1922); see Morser v. Bengor Products Co., 283 F. Supp. 926, 928 (S.D.N.Y. 1968). "Copying" is used here in the ordinary sense of the word; "copy," however, has become a term of art in copyright law, see M. NIMMER, ON COPYRIGHT \& 25.3 (1976). Whether videotape constitutes a "copy" was the focus of several early discussions on infringement and videotape reproduction.

One discussion, Meagher, Copyright Problems Presented by a New Act, 30 N.Y.U.L. RH: 1081,1098 (1955), concluded that reproduction of other copyrighted material by videotape recording would not infringe the copyright owner's right to copy under section 1(a) of the old Act. This conclusion was based on the highly technical definition of "copy" derived from the reasoning in White-Smith Music Pub. Co. v. Apollo Co., 209 U.S. 1 (1907). There, the Court held that a player piano music roll was not a copy of copyrighted sheet music. To be a "copy," a thing must be perceivable as a copy of the copyrighted material by the eye: "When the combination of musical sounds is reproduced to the ear it is the original tune as conceived by the author which is heard. These musical tunes are not a copy which appeals to the eye." Id. at 17. This definition of copy is now antiquated. Congress, by the Sound Recording Act of 1971, 17 U.S.C. § 1(f) (Supp. V 1975); H.R. REP. No. 487 at 6, and by the definitions of "copy" and "audiovisual works" in the new act, 17 U.S.C.A. $§ 101$ (West 1977), laid to rest Meagher's argument. Other than the semantical problem, Meagher saw little difficulty in concluding that 
elements of the copying requirement as (1) an absence of independent production; and (2) either an impermissibly low level of abstraction or excessive verbatim quoting of the copyrighted work. ${ }^{21}$ The independent production criterion simply means that the genesis of the defendant's work be derived from the copyrighted work. A presumption of the lack of independent production arises upon proof that the defendant had access to the copyrighted work. The presumption can be overcome by a showing of "strong, convincing and persuasive evidence" of independent creation on

using videotape to reproduce copyrighted material would be an infringement. 30 N.Y.U.L. REV. at 1094, 1099.

Meagher's conclusions are challenged in Fritch, Some Coypright Implications of Videotapes (Suggesting the Need for Statutory Revision), 13 ASCAP COPYRIGHT L. SYMP. 87 (1964) reprinted in 37 S. CALIF. L. REv. 214 (1964). The article discussed the possible use of the reasoning of Patterson v. Century Prods., Inc., 93 F.2d 489 (2d Cir. 1937), cert. denied, 303 U.S. 655 (1938), to circumvent the holding of Apollo. In Patterson, the court held that infringement occurred not only when a negative was made of a motion picture film, but also when the film was shown by the infringers. Id. at 493. The use of Patterson would "foreclose the use of private tapes taken off the air for noncommercial purposes . . . . Since courts certainly would not be anxious to reach such harsh results without express legislative direction, they may be quite prone to let Patterson drop by the wayside." 13 ASCAP COPYRIGHT L. SYMP., supra, at 117-18.

20. See Sid \& Marty Krofft Television Prods., Inc. v. McDonald's Corp., 562 F.2d 1157, 1162 (9th Cir. 1977); Reyher v. Children's Television Workshop, 533 F.2d 87, 90 (2d Cir.), cert. denied, 429 U.S. 980 (1976); Leonard Silver Mfg. Co. v. Lillian Vernon Corp., No. 77-4147 (S.D.N.Y. Nov. 3, 1977); McGraw-Hill, Inc. v. Worth Publishers, Inc., 335 F. Supp. 415, 419 (S.D.N.Y. 1971),

21. Comment, Copyright Fair Use-Case Law and Legislation, 1969 Duke L.J. 73, 78-79. Copying is alternatively formulated to require access to the copyrighted work and substantial similarity between the copyrighted and the infringing work. Reyher v. Children's Television Workshop, 533 F.2d 87, 90 (2d Cir.), cert. denied, 429 U.S. 980 (1976); Leonard Silver Mfg. Co. v. Lillian Vernon Corp., No. 77-4147 (S.D.N.Y. Nov. 3, 1977); M. NimMER, supra note 19, at $\S \S 139.4,141.2$. Substantial similarity is a question of whether the average observer would recognize the alleged copy as having been appropriated from the copyrighted work. Herbert Rosenthal Jewelry Corp. v. Honora Jewelry Co., 509 F.2d 64, 65 (2d Cir. 1974); Mode Art Jewelers Co. v. Expansion Jewelry Co., No. 77-519 (S.D.N.Y. Nov. 30, 1977). Recently, the Ninth Circuit criticized this orthodox formulation of copying as "boilerplate." Sid \& Marty Krofft Television Prods., Inc. v. McDonald's Corp., 562 F.2d 1157, 1162 (9th Cir. 1977). In $M c D o n a l d ' s$, the court outlined a bifurcated test for substantial similarity. First, an "extrinsic" test is to be employed to determine the substantial similarity of the general ideas. Id. at 1164. The test is extrinsic because it, involves analysis of criteria such as type of art work involved, materials used, subject matter and setting of the subject. Id. Second, an "intrinsic" test measures the substantial similarity between the forms of expression. This test is the ordinary observer test noted above. The test is intrinsic because it relies on the reasonable man's reaction, rather than on the identifiable criteria used in the extrinsic test. Id. McDonald's' extrinsic test does not analyze a matter irrelevant to copyright-the copying of ideas-despite the court's unfortunate choice of words, but it does determine whether there is an impermissibly low level of abstraction. Id. at 1163-64. See, e.g. , Bradbury v. CBS, Inc., 287 F.2d 478 (9th Cir. 1961), cert. denied, 368 U.S. 801 (1962) (a television show held toinfringe the copyright of a book because not only does the show have the same general scheme of the book, but also twenty-two nearly identical incidents), discussed in Comment, supra, at 78 n.35. 
the part of the defendant. ${ }^{22}$ The question of the impermissibly low level of abstraction involves a determination of the point, in a spiral of higher and higher abstraction from a copyrighted work, at which the defendant's "inspiration" from a copyrighted work becomes merely an appropriation of ideas, not an appropriation of the copyright owner's particular expression of those ideas. ${ }^{23}$ If the "inspiration" is abstract enough, there is no infringement. ${ }^{24}$

The salesman demonstrating Betamax and the home user had access to plaintiffs' works as they were broadcast over the air. That the Betamax reproduced identical copies is not in doubt. Thus, the valid copyrights on plaintiffs' works were arguably infringed by Betamax copying, absent a showing of an equitable defense.

Aside from the potential liability flowing from the recording involved in sale demonstrations, ${ }^{25}$ the joint, direct liability of the corporate defendants-the makers, distributors and sellers-turns on the liability of the home user. ${ }^{26}$ If the vidiot is not liable for his home recording, then his supplier cannot directly infringe by simply making and selling Betamax to him. ${ }^{27}$ Further, the availability of vicarious liability (which requires a right and an ability to supervise the infringing activity and a financial interest therein ${ }^{28}$ ) and contributory liability (which requires that the defendants knowingly aid,

22. Mode Art Jewelers Co. v. Expansion Jewelry, Ltd., No. $75-519$ (S.D.N.Y. Nov. 30, 1977).

23. Nichols v. Universal Pictures Corp., 45 F.2d 119, 121 (2d Cir. 1930), cert. denied, 282 U.S. 902 (1931); see Schroeder v. William Morrow \& Co., 566 F.2d 3, 5 (7th Cir. 1977).

24. See discussion of the McDonald's. "extrinsic" test in note 21 supra.

25. The sale demonstrations of Betamax are infringing acts. As noted, all the prima facie requisites of infringement are met. Further, the equitable defense of "fair use" and its corollary "home use" are inapplicable. The sales demonstration fails to fit the criteria for fair use outlined in the text accompanying note 157 infra and for home use, enumerated in the text accompanying notes $159-160$ infra.

26. See note 33 infra. Plaintiffs argue that the manufacture, sale and advertisement of Betamax infringe their copyrights. Pre-Trial Memorandum for Plaintiff at 9. However, since Betamax itself does not infringe, the entire line of reasoning depends on whether the core activity-the copying-is infringement. Compare this fact situation with the one in Ideal Toy Corp. v. Kenner Prod. Div. of Gen. Mills Fun Group, Inc., 443 F. Supp. 291,299 (S.D.N.Y. 1977), where the defendants, licensee and owner of copyrights to the movie "Star Wars" counterclaimed that plaintiff's "manufacture, importation, packaging, promotion, sale or other distribution" of "Star Team" toys infringed those copyrights. Kenner had the license to manufacture "Star Wars" toys. It is evident that in this situation, the items themselves-the "Star Team" toys-can infringe, whereas Betamax cannot.

27. Electra Records Co. v. Gem Electronics Dist. Co., 360 F. Supp. 821 (E.D.N.Y. 1973), discussed at notes 145-51, infra, is not on point here. There, although a customer deposited his 50 cents in the Make-A-Tape machine, it was the company that essentially did the copying-by owning the recorders and the records that were recorded, and by selling the blank tapes to the customers. It was "mass piracy on a custom basis." Id. at 825 .

28. See Gershwin Pub. Corp. v. Columbia Artists Management, Inc., 443 F.2d 1159 (2d Cir. 1971); Shapiro, Bernstein, Inc. v. H.L. Green Co., 316 F.2d 304 (2d Cir. 1963). 
abet or contribute to the infringement ${ }^{29}$ ) also depends upon the liability of the home user. In patent law, "it is settled that if there is no direct infringement . . . there can be no contributory infringement." 30 The same reasoning applies to copyright infringement. It is difficult to conceive of a secondary infringement when the activity to which it is related is not an infringement. In its rejection of an amendment to exempt proprietors of establishments such as nightclubs from liability for infringements by performers, the House Committee on the Judiciary recognized primary liability as a prerequisite to secondary liability. According to the committee, vicarious liability in the night club situation turns on whether the proprietor controls the operation of the establishment or the contents of the infringing program, and on whether he derived commercial gain from the performance. ${ }^{31}$ If the program were not infringing, the proprietor would not be liable. Furthermore, fair use is not "privileged infringement"; it is not infringement at all. ${ }^{32}$ Thus, the doctrine that one joint tortfeasor is not relieved from liability simply because the other joint tortfeasor is privileged or immune ${ }^{33}$ has no application here. The determinative liability, then, is that of the home user. Whether his liability, and consequently the liability of the sellers, makers and distributors can be established depends on whether the vidiot can prove either of the available equitable defenses: fair use or its emerging corollary, home use.

\section{Developments in the Exclusive Right to Perform IN Public}

Recent cases under the old copyright act ${ }^{34}$ concerning the exclusive right to perform and the congressional reaction to them as reflected in the

29. Gershwin Pub. Corp. v. Columbia Artists Management, Inc., 443 F.2d 1159 (2d Cir. 1971); Screen Gems-Columbia Music, Inc. v. Mark-Fi Records, 256 F. Supp. 399 (S.D.N.Y. 1966). See generally Annot. 14 A.L.R. Fed. 825 (1973).

30. Aro Mfg. Co. v. Convertible Top Replacement Co., 365 U.S. 336, 341 (1961) (emphasis in original).

31. H.R. REP. No. 1476 at 159.

32. 17 U.S.C.A. § 107 (West 1977) (new act). See also Shipman v. R.K.O. Radio Pictures, Inc., 20 F. Supp. 249, 250 (S.D.N.Y. 1937). However, some confusion on this point did exist under the old Act. Needham, Tape Recording, Photocopying, and Fair Use, 10 ASCAP COPYRIGHT L. SYMP. 75, 79 (1959).

33. RESTATEMENT OF TORTS $\$ 880$ (1934).

34. Section one provides that it shall be the exclusive right of the owner of copyright:

(d) To perform or represent the copyrighted work publicly if it be a drama, or, if it be a dramatic work and not reproduced in copies for sale, to vend any manuscript or any record whatsoever there of; to make or to procure the making of any transcription or record thereof by or from which, in whole or in part, it may in any manner or by any method be exhibited, performed, represented, produced, or reproduced; and to exhibit, perform, represent, produce, or reproduce it in any manner or by any method whatsoever; and

(e) To perform the copyrighted work publicly for profit if it be a musical composition ....

17 U.S.C. $\S 1(d),(e)(1970)$. 
new Act form a conceptual framework that is helpful in analyzing problems concerning the right to copy. Several reasons support the analogy between the right to perform and the right to copy or record. First, the Supreme Court's decisions in the area of public performance represent its most significant recent addition to the body of copyright law. Thus, by scrutinizing the policies that lie behind both the Supreme Court cases and the congressional reaction to them, one can gain insight into the latest thinking of Congress and the Court on the proper approach to take when questions of infringement arise. Second, the rights to copy and publicly perform are both subject to the stress caused by the evolution of modern electronic communications; that is, as the possible methods of public performance expanded through the electronic communications system, the sources and methods of copying have also expanded. Finally, in both areas it must be recognized that the equitable defenses operate to defeat what would otherwise be the copyright owner's exclusive rights. Although the "exclusive" rights to copy and to publicly perform cover different types of conduct, the term "exclusive" connotes the same idea in both areas-namely, that it is the copyright owner's sole prerogative to do what he chooses with the copyrighted object, subject only to an equitable defense.

In considering the right to perform, it must be kept in mind that the conclusions that have been reached in the radio broadcast area are at odds with those affecting cable television (CATV). ${ }^{35}$ Whereas developments in CATV support a finding of liability for use of Betamax, the developments in the radio broadcast area support a finding of non-liability. The following section discusses copyright infringement of radio broadcasts and focuses primarily on the recent case of Twentieth Century Fox Corp. v. Aiken ${ }^{36}$ Aiken suggests two possible grounds for non-liability: (1) de minimus performance and (2) implied-in-law consent. This Comment will examine both possible grounds and conclude that the first, but not the second, constitutes a viable arguement against liability.

\section{A. Aiken and De Minimus Performance.}

Aiken was the final case in a series of decisions that began with Buck $v$. Jewell-LaSalle Realty Co ${ }^{37}$ In Jewell-LaSalle, the defendant's hotel maintained a "master radio receiving set" wired to supply music by speaker and headphones to all public and private rooms in the hotel. ${ }^{38}$ Neither the radio

35. Cable television or community antenna television systems require the construction of a large antenna capable of receiving weak television signals. These signals are rebroadcast to paying customers. See notes 60-75 infra and accompanying text.

36. 422 U.S. 151 (1975).

37. 283 U.S. 191 (1931).

38. Id. at 195. 
station nor the hotel was licensed by the American Society of Composers, Authors, and Publishers (ASCAP) to publicly perform plaintiff's songs. ${ }^{39}$ Disregarding prior authority on the meaning of "perform," 40 the Court held that the hotel's mere reception of songs for the benefit of its patrons from a radio station without a copyright license to broadcast the songs violated the copyright owners' exclusive rights to publicly perform for profit. ${ }^{41}$ This holding was widely thought to require business establishments to obtain broadcast licenses to receive and play radio music for patrons of the establishments to avoid potential copyright infringement. ${ }^{42}$

Within the past ten years, the Court has increasingly narrowed the scope of Jewel-LaSalle. The cases that initially signaled the demise of Jewell-LaSalle arose in the context of CATV. ${ }^{43}$ In Fortnightly Corp. $v$. United Artists Television, Inc. ${ }^{44}$ plaintiff sued for infringement of its copyrights in motion pictures by a CATV cable television company that received broadcasts of United Artists' programs over five stations and carried them to Fortnightly's customers. The customers lived in a hilly region from fifty-two to eighty-two miles from the points of broadcast, making ordinary reception very difficult. The cable company originated no broadcasts and carried the stations' broadcasts in their entirety. The Supreme Court concluded that the principle of decision as to whether there was a "performance" focused on whether the function of the CATV fell into a "broadcasting" or a "viewing"' category. ${ }^{45}$ It was held that the function of the CATV fell "on the viewer's side of the line" ";6 hence the CATV was deemed not liable for publicly performing United Artists' copyrighted programs.

Teleprompter Corp. v. CBS, Inc. ${ }^{47}$ extended the functional broadcaster-viewer analysis. Owners of the copyrights in television programs sued five CATV systems for infringement by public performance. The cable systems were more sophisticated than the one in Fortnightly and carried the signals up to 450 miles from the point of original transmission. Reception at that distance by ordinary antennas would have been impossible. The Second

39. Id. at 199.

40. Buck v. Debaum, 40 F.2d 734 (S.D. Cal. 1929); Jerome H. Remick \& Co. v. General Elec. Co., 16 F.2d 829 (S.D.N.Y. 1926).

41. 283 U.S. at 199-200.

42. See H.R. REP. No. 1476 at $86-87$.

43. There is a wealth of material on cable television. See, e.g., Note, CATV and Copyright Liability: Teleprompter Corp. v. Columbia Broadcasting System, Inc., The Consensus Agreement, 25 HASTINGS L.J. 1507 (1974).

44. 392 U.S. 390 (1968).

45. Id. at 397 .

46. Id. at 399.

47. 415 U.S. 394 (1974). 
Circuit distinguished cable systems that carried the broadcast signals within an area in which viewers could pick up the signals with ordinary antennas from those that carried the signal beyond the capability of ordinary antennas. It held that the former, carrying "community signals," merely enhanced the viewer's capacity to receive and thus constituted no infringement, whereas the latter, the carrying of "distant signals," was in the nature of a broadcast falling within the context of a performance and hence was an infringement. ${ }^{48}$ The Supreme Court affirmed the decision as to community signals but reversed the decision as to distant signals. The Court found that technical differences between the distant and community signals did not change the function of the CATV. It then concluded, in view of its assessment that the carrying of distant signals would not "interfere in any traditional sense" 49 with the value of the copyright, that even the distant signal carrier was functionally a "viewer."

Fortnightly's and Teleprompter's erosion of Jewell-LaSalle laid the groundwork for Aiken. In Aiken, the owner of a small, fast-service restaurant installed a radio with four speakers in his restaurant and played the radio during business hours. Although the station that Aiken's radio received was licensed by ASCAP to publicly broadcast plaintiff's copyrighted songs (unlike the situation in Jewell-LaSalle), Aiken himself was not so licensed. ${ }^{50}$ Plaintiff's suit alleged that Aiken's playing of the radio at his business establishment violated plaintiff's exclusive right of public performance. ${ }^{51}$ The Supreme Court held, on the basis of Fortnightly and Teleprompter, that reception of a broadcast cannot be a "performance" if the broadcaster is licensed. ${ }^{52}$ Thus Aiken narrowly limits, and arguably overrules, JewellLaSalle. ${ }^{53}$

The Aiken Court held that although the radio was played in a commercial setting, there was no violation of the section 1(e) right to publicly perform for profit. To play the radio was functionally not to perform. ${ }^{54}$

48. Id . at 401. Additional distinctions from Fortnightly were that the Teleprompter systems originated some shows, the defendants sold commercial space on distant signals to local advertisers and the CATV systems sold the broadcasts to each other. Id. at 404. These factors were held insignificant. Id. at 405 .

49. Id. at 412 . The Court reasoned that the advertisers and not the viewers buy from the broadcaster and the advertising rates are based on expected numbers and types of audiences; it found that CATV does nothing to the system but change the numbers. Thus, it concluded, the introduction of the distant signals does not alter the profitability of the copyright. Id. at 411-12.

50. 422 U.S. at 153.

51. See note 34 supra. 17 U.S.C. § 1(e) (1970).

52. 422 U.S. at 161-62.

53. Id. at 162, 166 (Blackmun, J., concurring); M. NIMMER, supra note 19, at $\S 107.41$; Note, Twentieth Century Music Corp. v. Aiken: Are Broadcasting Signals Dedicated to the Public?, 36 U. PITT. L. REv. 994 (1975).

54. 422 U.S. at 161-62. As discussed in text accompanying notes $45-46$ supra, the Court in 
However, the Court went beyond this basis of decision-functional similarity to a viewer ${ }^{55}$-and suggested three alternate bases: first, to find an infringement in the case would create a practically unenforceable rule, ${ }^{56}$ given the countless number of small businesses; second, the receiving "performer" would be unable to guard against copyright infractions based on a broadcaster's unlicensed use of copyrighted songs; ${ }^{57}$ and third, if the small commercial establishments were considered to perform, the result would be the requirement of "untold numbers of licenses for what is basically a single public rendition of a copyrighted work." 58 These alternative bases imply that, even disregarding the definition of "performance," technical infringement will be modified by the principle of a de minimus violation. ${ }^{59}$ The notion of de minimus violation gains strength from and is clarified by Congress' reaction to Aiken.

The congressional reaction ${ }^{60}$ to the problem faced in Aiken is codified in 17 U.S.C.A. section $110(5)$ of the new copyright act. ${ }^{61}$ According to the House Committee on the Judiciary, section 110(5) codified "the traditional, pre-Aiken, interpretation of the Jewell-LaSalle decision under which public communication by means other than a home receiving set, or further transmission of a broadcast to the public, is considered an infringing act." However, a more accurate statement of the effect of section $110(5)^{63}$ is that

Teleprompter and Fortnightly laid down the test for "performance" used in Aiken which distinguished functionally between a performer's actions and a viewer's actions.

55. "[I]f Fortnightly, with its elaborate CATV plant and Teleprompter with its even more sophisticated and extended technological and programming facilities were not 'performing,' then logic dictates that no 'performance' resulted when the [respondent] merely activated his restaurant radio." 422 U.S. at 16I-62 (quoting from the decision of the Third Circuit).

56. 422 U.S. at 162. See Newsweek, Oct. 31, 1977, at 69, col. 1). By autumn of 1977 several prominent television manufacturers had their own videotape recorders on the market. With an intensive advertising campaign planned, producers were hoping to sell 250,000 units by Christmas, 1977, and 750,000 in 1978 . Prices continue to fall, opening the market to an expanding group of buyers. See Wall St. J., March 29, 1978, at 1, col. 6.

57. 422 U.S. at 162.

58. Id. at 163 .

59. See Needham, supra note 32 , at $83,86-87$.

60. The legislative recognition that there should be an exemption from liability for a small business with a home-type system dates to 1961 . Second Supplementary Report, c.4 at 3-6; see also 17 U.S.C.A. \& 111(a) (West 1977) (new act).

61. $\$ 110$. [T] he following are not infringement of copyright: . . .

(5) communication of a transmission embodying a performance or display of a work by the public reception of the transmissions on a single receiving apparatus of a kind commonly used in private homes, unless-

(a) a direct charge is made to see or hear the transmission; or

(b) the transmission thus received is further transmitted to the public . . . .

62. H.R. REP. No. 1476 at 87 ; Second Supplementary Report, c. 4 at 11 .

63. The Register in his 1961 report to Congress conceded that, under Jewell-LaSalle, it was possible that any business establishment that operated a radio or television faced liability. He recommended an exemption to cover the "mere operation of receiving sets." Second Supplementary Report, c. 4 at 4 . Realizing that the question of liability had not been decided in the small business-home receiver situation, the Register, in the 1965 Supplementary Report, for- 
it codified the result in Aiken $^{64}$ while expressly rejecting its functional definition of performance. ${ }^{65}$ In other words, in Congress' view Aiken was rightly decided but for the wrong reasons. As Aiken correctly held, in a small commercial establishment the use of an ordinary home receiver with four ordinary loudspeakers is not an infringement. Since Congress rejected the Court's functional performance rationale, the facts in Aiken and its alternate bases for decision become significant in determining the applicability of Aiken exception for de minimus ${ }^{66}$ violations in other situations.

The Aiken rationale based on practical unenforceability seems appropriate to the Betamax situation. Enforcing an exclusive right to copy, unmodified by an exception for de minimus violations, would be just as "practically impossible" as enforcing an unmodified exclusive right to publicly perform. ${ }^{67}$ Practical unenforceability could have one of three meanings. First, it could be an expression of the Court's desire, as a matter of judicial administration, to refrain from "opening the floodgates" on litigation in this area. Second, practical unenforceability could mean "overwhelming numbers," that is, the sheer number of potential infringements

mulated an exception similar to section 110(5) that was intended "[t]o make clear that it is not an infringement of copyright merely to turn on, in a public place, an ordinary radio or television receiving apparatus of a type commonly sold to members of the public for private use." Id. at 5. A House Committee report following the Register's report concurred and stated that the potential for abuse of the exception did not justify "making vast numbers of small business and professional people guilty of technical infringements." Id. at 6 (emphasis added). It appears then that prior to Aiken, the Register and Congress were not at all sure whether the Aiken-type use was an infringement under existing law.

64. Under the particular fact situation in the Aiken case . . . it is intended that the performance would be exempt under clause (5). However, the Committee considers this fact situation to represent the outer limit of the exemption. . . . Thus, the clause would exempt the small commercial establishments whose proprietors merely bring onto their premises standard radio or television equipment . . . but it would impose liability where the proprietor has a commercial "sound system" installed or converts ... [home equipment into the equivalent].

H.R. REP. No. 1476 at 87.

65. "The majority of the Supreme Court in the Aiken case based its decision on a narrow construction of the word 'perform' in the 1909 statute. This basis for the decision is completely overturned by the present bill . . . ." H.R. REP. No. 1476 at 87; accord, Second Supplementary Report, c. 4 at 11.

66. The de minimus character of the Aiken facts stems from use by a small business of ordinary, unadapted radio and television sets to incidentally entertain patrons.

67. It could be argued that since Congress codified the principle for de minimus performances in section $110(5)$, by negative implication the principle is inapplicable in other areas, such as the right to reproduce, section $106(1)$. On the other hand, section 110(5) is a codification of an exemption, not the creation of a new one. A negative implication should arise much more quickly in the latter than in the former case. Further, it can be said that statutory recognition of a situation where common law determines the absence of infringement in one category does not foreclose the situation from arising in a different category, with similar consequences. After all, Aiken is a performance case. It is entirely reasonable to say that congressional treatment of the Aiken situation in a performance context is simply an approval of the principle of de minimus infringements in the concrete context in which it has arisen. Disapproval is not thereby implied for all other situations. 
precludes any systematic vindication of the copyrights. ${ }^{68}$ "Overwhelming numbers" is probably the Court's interpretation of practical unenforceability; nevertheless it seems illogical to argue that because there are massive violations of a copyright, the violations are therefore of a de minimus nature. ${ }^{69}$ The third possible meaning of practical unenforceability is that the individual violations have an insignificant impact. This would suggest that, in the Aiken situation, it is a waste of time and money to attempt to enforce against small shopkeepers or restauranteurs since the impact of each infringement would be insignificant. ${ }^{70}$ The insignificant impact interpretation, of course, does not look to the combined impact of individual uses but only to the isolated impact of a single individual's uses.

The second alternative basis in Aiken-inability to avert infringement-is essentially inapplicable in the Betamax situation. ${ }^{71}$ The third alternative basis of Aiken concerns the geometric expansion of the potential profitability of copyrights. That is, after the copyright owner licenses a broadcasting station to perform his work, he stands to profit again when the work is broadcast, under Jewell-LaSalle, by licensing the multitude of small shopowners who play the broadcast on their sets. This basis also supports a holding of non-liability from Betamax use.

Although arguably offset by a decline in re-run revenues, the potential for increased liability for copyright infringement (or increased susceptibility to some future licensing agreement) is comparable to the potential increase in liability that the Court rejected in Aiken. Most importantly (and as

68. Yet, it could be argued that the manufacturers of videotape recorders, through their intensive promotion campaigns for Christmas, 1977, were attempting to create such a situation and thus to present the court with a fait accompli.

69. Even if "practically impossible" is defined to mean "overwhelming numbers," it could be argued that the proper approach to infringement is not to collect individual users and add together their impact. This contention is plausible because the association of "overwhelming numbers" and de minimus is a contradiction in terms: massive numbers are, by definition, not de minimus. Thus, associating overwhelming numbers and de minimus suggests that it is not the collective impact, but the individual impact, that is de minimus.

70. The insignificant impact interpretation receives some support by the Court's notation that "[a]s a matter of so-called 'policy' or 'practice,' . . . ASCAP has not even tried to exact licensing agreements from commercial establishments whose radios have only a single speaker." 422 U.S. at 162 n.12. This interpretation of the "practically impossible" language rests upon the impact of an individual's actions rather than the impact of a class' actions. Even if the Court meant "overwhelming numbers", see text accompanying note 69 supra, no practical difference separates the "overwhelming numbers" interpretation from the insignificant impact interpretation. The collective impact of an "overwhelming number" of performances simply cannot be de minimus.

71. The restaurant owner who plays a radio for his customers cannot ascertain that the radio station has not received a license for a song and that the latter is therefore infringing. By contrast, the Betamax home user, assuming that proper licensing by a television broadcaster will not absolve the recorder as it will the small "performer," can simply not record a copyrighted show. 
Congress has noted) the facts of Aiken suggest a common sense notion of a de minimus violation: there is a difference in kind between the home user and the recording pirate.

One apparent factor supporting liability for vidiots is the enactment of section 111 of the new copyright act. ${ }^{72}$ Congress essentially agreed with the Second Circuit's analysis in Teleprompter as to the significance of the difference between local and distant signals ${ }^{73}$ when it required that all retransmissions beyond the "local service area" be licensed. However, Congress only made the carrying of distant signals subject to the compulsory license; as under Fortnightly, the carrying of local signals does not create liability. In so drawing the line, Congress apparently recognized the economic impact of copyright infringements and thus went to the heart of the economic incentive rationale of copyright law. "The Judiciary Committee has tried to resolve each issue by applying the standard of what best promotes the constitutional mandate to encourage and reward authorship." 74 In this manner, Congress emphasized economic impact over the existence or non-existence of a profit motive by the retransmitter. Even though all cable systems engage in the secondary transmissions with intent to profit, only some, based on their economic impact, are liable to the owners of copyright. This might suggest that the users of Betamax should be held liable because they will have an adverse collective impact on the plaintiffs' market. However, it must be noted that section 111 is essentially addressed to cable systems which one House Report specifically characterized as "commercial enterprises."75 Further, sections 111(a)(1) and (4) provide that a secondary transmission is not an infringement if it is made by a government or other nonprofit organization, or by a hotel or apartment house to its guests without a direct charge. This suggests that although Congress did not intend that the existence of a profit motive always triggers

72. Under section $111(\mathfrak{f})$, all carrying by a cable system is a "secondary transmission." Fees for the compulsory license are due, on differing percentages, on two bases. First, transmitters broadcasting secondary transmissions beyond the "local service area" of the "primary transmitter," which, although not defined in section 111 , is a station that originally broadcasts signals (and also a cable system whose signals are being rebroadcast by another cable system) must pay a fee, see 17 U.S.C.A. \& 111(f) (West 1977), H.R. REP. No. 1476 at 88. Second, fees are also calculated on percentages of gross income based on "distant signal equivalents," 17 U.S.C.A. $\$ 11$ (d)(2)(B) (West 1977). Distant signal equivalents are defined in terms of secondary transmissions beyond the local service area, id. $\$ 111(\mathrm{f})$. Local service area is essentially the area from which the primary transmitter's signals can be received, see id. $\S$ 111(f); H.R. REP. No. 1476 at 99. Thus, although there are further distinctions between the types of programs carried, liability is determined along the lines of economic impingement. For a good summary of the legislative history of section 111, see Second Supplementary Report, c.5 at 2-26.

73. H.R. REP. No. 1476 at 90, 99; Second Supplementary Report, c.5 at 28 \& 29.

74. 122 CoNG. REC. S1546 (daily ed. Feb. 6, 1976) (remarks of Senator McClellan).

75. H.R. REP. No. 1476 at 89. 
liability, it did consider profit motive to be a significant factor in determining liability.

In summary, Aiken and the congressional response to it create a de minimus exception to infringement of the right to perform that could easily form the basis for an exception to liability in the Betamax/right to copy context. Home use of Betamax fits readily within most possible constructions of the exception for de minimus violations. However, the establishment of the compulsory license system for cable systems carrying distant signals (but not for those carrying only local signals) supports the argument that liability should be premised on adverse economic impact. Such adverse economic impact in the Betamax situation would appear to be in the cumulative impact of Betamax users on the copyright's value. The cable television development could then easily form the basis of a finding of liability in the Betamax context.

\section{B. Aiken and Implied Consent. ${ }^{76}$}

In Jewell-LaSalle, neither the hotel nor the radio station was licensed to perform plaintiff's songs. The Court suggested that if the radio station had been licensed, a license for commercial distribution might have been implied, ${ }^{77}$ and that the decision in Buck v. Debaum ${ }^{78}$ would then have been controlling.

In Debaum, the owner of a popular cafe in Los Angeles installed a radio receiver in the cafe and received plaintiff's copyrighted song from a radio station that was licensed by ASCAP to broadcast it. The court held for the defendant cafe owner on two grounds: that the act of turning on a radio, making audible the sound waves present, did not constitute "performance" under copyright law; and that by licensing the radio station, "[the copyright owner] must be held to have acquiesced in the utilization of all forces of nature that are resultant from the licensed broadcast . . . "79 Although Debaum has been distinguished ${ }^{80}$ and rejected sub silentio, ${ }^{81}$ it was revived by the recent Supreme Court cases that cut back drastically the scope of Jewell-LaSalle. In Fortnightly, the Court noted that the Jewell-LaSalle court might have held differently if the radio station had been licensed and that Jewell-LaSalle "must be understood as limited on its own facts." 82 In

76. See generally M. NIMMER, supra note 19 , at $\S 107.43$; Pre-Trial Memorandum for Defendant at $45-47$.

77. 283 U.S. at 198,199 n.5.

78. 40 F.2d 734 (S.D. Cal. 1929).

79. Id. at 736 (emphasis added).

80. Famous Music Corp. v. Melz, 28 F. Supp. 767, 769 (W.D. La. 1939).

81. Society of European Stage Authors \& Composers, Inc. v. New York Hotel Statler Co., 19 F. Supp. 1 (S.D.N.Y. 1937).

82. 392 U.S. at 397 n. 18. 
Aiken, which did limit Jewell-LaSalle to the facts of the case, the Court again referred to the Jewell-LaSalle/Debaum distinction. ${ }^{83}$

On this basis, it has been argued that a "license to the station implies, as a matter of law, a license for multiple performance as well." 84 The applicability of this argument to the use of Betamax appears at first blush to be strained, not only because there was an alternate holding in Debaum, but because the infringement alleged in Betamax is copying, not performing. ${ }^{85}$ However, this potential interpretation of copyright law might be viewed as a convenient tool to protect an arguable public interest in the airwaves. Debaum suggests the importance of this public interest in holding that the copyright owner acquiesced to all "forces of nature" resulting from that broadcast by issuing the license to the station. ${ }^{86}$ Teleprompter Corp. $v$. CBS, Inc. ${ }^{87}$ reflects the Debaum approach. There, the court argued:

When a television broadcaster transmits a program, it has made public for simultaneous viewing and hearing the contents of that program. The privilege of receiving the broadcast electronic signals and of converting them into the sights and sounds of the program inheres in all members of the public who have the means of doing so. ${ }^{88}$

The reasoning that something special happens for copyright purposes when materials are broadcast over the air does not imply that the copyright owner surrenders all property rights in his work upon its broadcast. Broadcasting material capable of being copyrighted does not "publish" the material and place it in the public domain, thereby rendering the work uncopyrightable. ${ }^{89}$ Nor does the fact that the television station broadcasts without license a copyrighted item over the public airways immunize the station from liability.$^{90}$ Indeed, at least one case clearly holds that copying

83. 422 U.S. at 160 .

84. M. NimMER, supra note 19 , at $\$ 107.43$.

85. In other words, it is harder to say that copying is implied from the licensing to broadcast than it is to say that multiple performances are implied from the license. The "performances"nothing more than turning on the receiver and listening-are exactly what is contemplated by the license. The public, by tuning in, does what is necessary to complete the performance; the tuning in provides the audience. But copying by the public is a step beyond; it is not necessary to complete the performance.

86. 40 F.2d at 736 .

87. 415 U.S. 394 (1974).

88. Id. at 408. See Pre-Trial Memorandum for Defendant at 27-31.

89. American Tobacco Co. v. Werckmeister, 207 U.S. 284 (1907); King v. Mister Maestro, Inc., 224 F. Supp. 101 (S.D.N.Y. 1963); Uproar v. NBC, Inc., 8 F. Supp. 358 (C.D. Mass. 1934); CBS, Inc. v. Documentaries, Unlim., 42 Misc. 2d 723, 248 N.Y.S.2d 809 (Sup. Ct. Special Term, 1964).

90. Smothers v. CBS, Inc., 359 F. Supp. 723 (C.D. Cal. 1973). But see Mura v. CBS, Inc., 245 F. Supp. 587 (S.D.N.Y. 1965). In Mura, plaintiff was the owner of copyrights on certain hand puppets and defendant broadcast the "Garfield Goose Show." Without any consent requested or given, defendant broadcast images of Mura's puppets on the show for approximately thirty-five seconds. While it was broadcasting the show, CBS made a film recording of 
or recording broadcasted materials consitutes copyright infringment. ${ }^{91} \mathrm{Walt}$ Disney Productions v. Alaska Television Network ${ }^{92}$ is a cablevision case that was decided shortly after the Supreme Court's decision in Fortnightly. Walt Disney claimed infringement of its copyrighted motion picture photoplays on the basis that the defendant recorded broadcasts received from television stations on videotape. The recording was an integral step in the process whereby defendant carried television broadcasts from Seattle and Tacoma, Washington to Juneau, Alaska. ${ }^{93}$ These broadcasts were delayed up to a week. Although the decision is ambiguous on the crucial question of whether recording alone without commercial exploitation violates section 1(d), ${ }^{94}$ the court does appear to so hold: "The preparation of the video tapes of copyrighted materials infringed upon the rights of the copyright owner

the program. The court held that CBS did not infringe Mura's copyright under section 1(a) because the copy-an evanescent reproduction-was so different in form from the puppet and because CBS's use of the puppet was fair.

91. In Miller v. Goody, 125 F. Supp. 348 (S.D.N.Y. 1954), related case, 139 F. Supp. 176 (S.D.N.Y. 1956), rev'd sub nom. Shapiro, Bernstein \& Co. v. Goody, 248 F.2d 260 (2d Cir. 1957), defendant Krug consented to a decree of infringement for manufacturing records of a radio broadcast of Major Alton "Glenn" Miller and his A.E.F. Orchestra, which contained nine copyrighted musical compositions. 248 F.2d at 261 . However, Krug's recording was not made off the air but rather from records of the broadcast. $139 \mathrm{~F}$. Supp. at 176. In CBS, Inc. v. Documentaries, Unlim., 42 Misc. 2d 723, 248 N.Y.S.2d 809 (Sup. Ct. Special Term, 1964), Documentaries recorded off the air a radio broadcast by a CBS news announcer about the assassination of President Kennedy and incorporated the announcement into a phonograph record produced for commercial distribution. 248 N.Y.S.2d at 810 . After holding that the broadcast was not a general publication, the court held that "[t]his is a clear case of appropriation for commercial profit of another's property right," 248 N.Y.S.2d at 812 . Thus, both the copying and the incorporating were elements of the tort; the case did not hold that the copying itself was either a state law or a federal copyright law violation. In Metropolitan Opera Ass'n, Inc. v. Wagner-Nichols Recorder Corp., 199 Misc. 786, 101 N.Y.S.2d 483 (Sup. Ct. 1950), plaintiff brought an action based on misappropriation because defendant recorded the opera's broadcasts off the air and sold recordings to the public. As in Documentaries, the gravamen of the action lay in the recordation of the broadcast and the commercial exploitation of the recording.

In Encyclopaedia Britannica Ed. Corp. v. Crooks, No. 77-560 (W.D.N.Y., Feb. 27, 1978), the court preliminarily enjoined the defendant, a non-profit corporation organized to provide educational services to public shools in Erie County, New York, from videotaping plaintiff's copyrighted motion pictures from television broadcasts and from recopying them for distribution to the schools. See note 159 infra. The court's holding that plaintiff had proven probable success on the merits without discussing the public's interest in the airwaves-especially in light of the fact that defendant's copying was for educational purposes-argues strongly against the implied in-law consent.

92. 310 F. Supp. 1073 (W.D. Wash. 1969).

93. Id. at 1074 .

94. Defendants could hardly contend that it would not be an infringement of copyright for one to receive the broadcast of a copyrighted song by way of radio, record it on a master disc, and then play it over another radio system or "Musak" system . . . . While the defendants did not make the videotapes available on a widespread basis, the video tapes were capable of being sold to any cable television station with the proper equipment.

310 F. Supp. at 1075 (first emphasis added; second in original). 
under $\S 1(\mathrm{~d})$, and the dissemination of the programs through defendants' cable system also constitutes an infringement." 95

Alaska Television involves CATV and could have been treated as a public performance case. However, in an apparent attempt to avoid the holding of non-liability in Fortnightly, it was treated as a copying case. For this reason, and because it involves commercial exploitation of the recording, Alaska Television has little precedential value for the Betamax case insofar as non-commercial recording is in issue. Furthermore, the precise holding of Alaska Television has been legislatively reversed by the new copyright act. ${ }^{96}$ However, interpreting the legislative reversal to mean that broadcast of a copyrighted work precludes copyright infringement is not warranted by the narrow scope of the legislative reversal and by section 112(a) of the new Act. ${ }^{97}$ The narrowness of the very technical reversal of Alaska Television certainly suggests that nothing special happens for copyright purposes on broadcast to shrink the protection of copyright.

The primary rationale for the implied consent theory in the Debaumpublic performance area is the similarity between the actions constituting the second public performance and actions necessary to complete the first public performance..$^{98}$ In other words, the act of turning on the TV or radio results in the second public performance, but that same act is a necessary step in completing the first public performance; otherwise, the program will have been broadcast but never received.

To extend the implied consent theory to encompass memorialization, however, requires a further rationale, one rooted in the first amendment. ${ }^{99}$

95. Id. at 1075 .

96. 17 U.S.C.A. $\S \S 111(\mathrm{e})$, (f) (West 1977). It is interesting to note that the legislative history of section 111(e) lends support to the rationale of the state off-the-air-recording cases discussed in note 91 supra and to the alternative interpretation of Alaska Productions, supra note 94: "With the one exception provided in subsection (f) and limited by subsection (e), the section does not cover or permit a cable system, or indeed any person, to tape or otherwise record a program off-the-air and later to transmit the program from the tape or record to the public." H.R. REP. No. 1476 at 91 (emphasis added). Again, there must be the combination of the recordation and the economic exploitation.

97. Sections $111(\mathrm{e})(2)$ and (f), paragraph 2, permit, under the compulsory license system, cable systems located outside the contiguous forty-eight states, Puerto Rico and to a limited extent Hawaii, to make recordings off-the-air of all materials to aid its delayed transmission to its subscribers. This was precisely the fact situation in Alaska Television. Thus, in this limited sense the cable system could avoid liability for the recording. The negative implications of sections 111 (e) and 112(a) make clear that this limited right to record a television show in a commercial setting does not extend beyond the geographical limitations of section 111(e). Section 112 permits all transmitting organizations-including cable systems without regard to geographic location-to make recordings of copyrighted material to aid in transmission. Section 112(a) does not, however, permit recording of motion pictures and other audiovisual works. Thus, although an Alaska cable system could record television shows broadcast from Washington state, an Idaho system could not.

98. See note 85 supra.

99. Defendants argue in their Pre-Trial Memorandum 26-31, 41-42, 45-47, that the first 
The Supreme Court has recognized that the technological limitations of access to the broadcast media require the elevation of the interest of the viewing and listening public over the interest of those broadcasting. ${ }^{100}$ The question is whether this choice of priorities, which gives the public the privilege "of converting [broadcast signals] . . . into the sights and sounds of the program," 101 includes the right to memorialize the sights and sounds on magnetic tape. The basis for the limitation on broadcaster discretion-the fairness doctrine-lies in the fundamental first amendment presumption that the "marketplace of ideas" will dialectically produce the truth. ${ }^{102}$ Given the physically limited ability to broadcast views, the artificial device of the "fairness doctrine" emerged in order to preserve the balance in the marketplace. ${ }^{103}$ Because the primary concern is the dissemination of information in a balanced way, the doctrine imposes a limitation on the "near monopoly" 104 of airwaves since it is the right of the viewers and listeners, not the right of the broadcasters, which is paramount. ${ }^{105}$

There are several reasons which could justify the extension of the public interest in the airwaves to limit property rights in copyright. First, both copyright and rights to broadcast are legislatively created, limited monopolies - the former in the use and benefit of the tangible expression of a person's thought; the latter in the utilization of a transmission frequency. Both stem not from any public policy for the creation of monopolies, but from practical concerns: the encouragement of useful arts and sciences and the avoidance of chaos in broadcasting frequencies. ${ }^{106}$ An affinity of structure exists between a copyright and a license to broadcast; when they become closely associated, as in the Betamax case, it is possible to switch the limitations on broadcasting onto copyright without structurally damaging either concept.

amendment implications of broadcast and implied consent should permit the memorializing of broadcasted materials.

100. Compare Red Lion Broadcast Co. v. FCC, 395 U.S. 367 (1967) with Miami Herald Pub. Co. v. Tornillo, 418 U.S. 241 (1974).

101. 415 U.S. at 408.

102. Red Lion Broadcast Co. v. FCC, 395 U.S. 367, 390 (1967); New York Times Co. v. Sullivan, 376 U.S. 254, 270 (1964).

103. "[B]roadcast frequencies are limited and, therefore, they have been necessarily considered a public trust. Every licensee who is fortunate in obtaining a license is mandated to operate in the public interest and has assumed the obligation of presenting important public questions fairly and without bias." S. REP. No. 562, 86th Cong., 1st Sess. 8-9 (1959), quoted in Red Lion Broadcast Co. v. FCC, 395 U.S. 367, 383 (1967).

104. Friendly, The Campaign to Politicize Broadcasting, Colum. Journalism Rev. Mar./Apr. 1973 at 9. The fairness doctrine requires the broadcaster to adequately cover issues of public importance and to fairly reflect differing viewpoints, CBS, Inc. v. Democratic Nat'l Comm., 412 U.S. 94, 111 (1973); Red Lion Broadcast Co. v. FCC, 395 U.S. 367, 377 (1967).

105. Red Lion Broadcast Co. v. FCC, 395 U.S. 367, 390 (1967); see United States v. Midwest Video Corp., 406 U.S. 649 (1972).

106. CBS, Inc. v. Democratic Nat'1 Comm., 412 U.S. 94, 104 (1973). 
Second, the operation of a Betamax machine appears to promote the principle underlying the fairness doctrine: the right of the public to be informed within the context of the "marketplace of ideas." 107 By enabling a person to memorialize a broadcast which exists only at a given time, it increases his ability to receive information by freeing him from the prior limitation of being in front of a television set at a specific time. ${ }^{108}$

Third, the enforcement of the fairness doctrine through the licensing process $^{109}$ produces a rationale for the incorporation of the implied consent theory: broadcast stations are licensed to broadcast only in the public interest. An important public interest lies in the promotion of the flow of information. Broadcast stations may not contract to broadcast in contravention of the promotion of the public interest. Therefore, any license to broadcast given by a copyright owner must carry the implied qualification that the broadcast promote the public interest, which includes permitting the use of Betamax to maximize the information flow.

Although the first amendment has not been asserted as a defense to actions for infringement in the context of the fairness doctrine, several courts have rejected first amendment defenses to actions for infringement largely because copyright in itself places " $[\mathrm{n}] \mathrm{o}$ restraint . . . on the use of an idea or concept." 110 Copyright is a limitation on the use of a form of an idea: it is a limited monopoly of form. A license to broadcast is also a limited monopoly of form-a licensed broadcaster has an exclusive right for a limited time in a limited area to use a frequency to communicate with the viewing and listening public. But it must be remembered that the grant of a license to one broadcaster prevents many others from communicating with the public over radio or television, except as allowed by the discretion of the licensee ${ }^{111}$ or by the fairness doctrine. The broadcasting license therefore limits the ability to communicate with others to the licensee. Assuming that

107. Id. at 112-13; see Pre-Trial Memorandum for Defendant, 26-31; Pre-Trial Memorandum for Plaintiff, 79-91.

108. It is arguably a long step from politically-oriented information flow (with which the fairness doctrine is primarily concerned) to the probable use of a Betamax for the recordation of entertaining programs. However, the Supreme Court appears to be increasingly hesitant to differentiate political and other forms of speech. See, e.g., Bates v. State Bar of Arizona, 97 S. Ct. 2691 (1977) (prohibition of the advertising of fees for routine legal services is an unjustifiable restraint of free speech); Virginia State Bd. of Pharmacy v. Virginia Citizens Consumer Council, 425 U.S. 748 (1976) (a ban on the advertisement of prices of prescription drugs is an unjustifiable restraint of free speech). Moreover, the use of Betamax might actually encourage political discussion-for instance, by recording the Nixon-Frost interviews. Freedom of Video, supra note 2 , at 60 , col. 2 .

109. Red Lion Broadcast Co. v. FCC, 395 U.S. 367, 394 (1967).

110. Goldstein v. California, 412 U.S. 546, 571 (1973); accord, Mazer v. Stein, 347 U.S. 201, 217 (1954); see Zacchini v. Scripps-Howard Broadcasting Co., 97 S. Ct. 2849, 2858 n.13 (1977); Pre-Trial Memorandum for Plaintiff at 79-81.

111. CBS, Inc. v. Democratic Nat’1 Comm., 412 U.S. 94, 111, 120 (1973). 
different people have different ideas, the license thus represents a limitation on the expression of ideas. By ]icensing the station to broadcast a copyrighted work, the owner of a copyright places his limited monopoly of form within the limited monopoly of expression. The broadcast of a copyrighted film or show, because it limits the expression of other ideas, necessarily subjects the copyrighted material to the interests of the public in the reception of the broadcasts. ${ }^{112}$ It should be noted, moreover, that none of the cases rejecting a first amendment defense involves the recordation of broadcasted material. ${ }^{113}$

However, none of these arguments is persuasive enough to compel a conceptual leap from the right to hear to the right to memorialize. The structural affinity of the copyright and broadcast licenses merely makes crossover conceptually clean; it does not mandate crossover of restrictions. Further, even if the crossover is made, it seems clear that the scope of the first amendment restriction implicit in technologically limited access is limited to the operation of the fairness doctrine. ${ }^{114}$ The limitation of expression of ideas inheres in the "broadcast" not in the "use of the copyrighted material." It stretches the imagination to the breaking point to say that the fairness doctrine affirms the following argument: because a person with one

112. See notes 91,94 \& 96 supra.

113. Goldstein v. California, 412 U.S. 546 (1973) (state statute prohibiting record "piracy"the commercial recordation and sale of another's record-does not violate first amendment); Wainwright Securities, Inc. v. Wall St. Transcript Corp., 558 F.2d 91 (2d Cir. 1977), cert. denied, 98 S. Ct. 730 (1978) (first amendment argument rejected when advanced by a weekly financial newspaper to defend its copying of financial reports of an institutional research business); United States v. Bodin, 375 F. Supp. 1265 (W.D. Okla. 1974) (pirating of records onto tapes); Jondora Music Pub. Co. v. Melody Recording, Inc., 362 F. Supp. 494 (D.N.J. 1973), rev'd on other grounds, 506 F.2d 392 (3d Cir.), cert. denied, 421 U.S. 1012 (1975) (piracy of records onto tapes); Robert Stigwood Gp., Ltd. v. O'Reilly, 346 F. Supp. 376 (D. Conn. 1972), rev'd on other grounds, 530 F.2d 1096 (2d Cir.), cert. denied, 429 U.S. 848 (1976) (public performance of copyrighted musical composition in concerts); Walt Disney Prod. v. Air Pirates, 345 F. Supp. 108 (N.D. Cal. 1972) (copying and reproduction of cartoon characters in a magazine); McGraw-Hill, Inc. v. Worth Publishers, Inc., 335 F. Supp. 415 (S.D.N.Y. 1971) (copying of one economic textbook by publishers of another).

However, in Sid \& Marty Krofft Television Prod., Inc., v. McDonald's Corp., 562 F.2d 1157 (9th Cir. 1977), a first amendment argument was rejected despite the fact that the copyrighted item was a children's television show, which was infringed by defendant's "McDonaldland" television commercials. 562 F.2d at 1171. Defendant did not record plaintiff's show; the court did not consider the possibility of a limitation on copyright based on the first amendment-rooted public interest in the airwaves. Nevertheless, it did recognize the "rare" limitation on copyright of graphic expressions of newsworthy events. Id. at 1171, which was first suggested in Nimmer, Does Copyright Abridge the First Amendment Guarantees of Free Speech and Press?, 17 U.C.L.A. L. REv. 1180,1199 (1970). See Time, Inc. v. Bernard Geis Associates, 293 F. Supp. 130 (S.D.N.Y. 1968).

114. CBS, Inc. v. Democratic Nat'l Comm., 412 U.S. 94, 121-22, 130-31 (1973) (broadcaster who must meet public obligation of providing full and fair coverage of public issues not required to accept editorial advertisements). 
television can only watch it on one channel at a time, because there is more than one channel, because the copyrighted show appears on a channel not being watched, and because the ideal of the fairness doctrine is an unskewed "marketplace of ideas," the copyright owner impliedly licenses all viewers not only to watch or perform in de minimus commercial settings, but also to memorialize. Must it not also follow that the seller of a television owes a duty to the buyer to enable him to watch five channels at the same time? Clearly, this goes too far.

Finally in Zacchini v. Scripps-Howard Broadcasting Co. ${ }^{115}$ the Supreme Court held that the first amendment did not immunize the news media from a claim based on a state tort law "right of publicity." In that case, a cameraman from a television station filmed the entire act of Zacchini, who was a "human cannonball." Zacchini previously had denied permission to film the act. Noting that the right of publicity promoted the public interest by giving the performer economic incentives to perform, in a manner similar to the economic incentives used by copyright law, the court stated: "The Constitution no more prevents a State from requiring respondent to compensate petitioner for broadcasting his act on television than it would privilege respondent to film and broadcast a copyrighted dramatic work without liability to the copyright owner."116 Zacchini is analogous support for the proposition that a television station infringes by broadcasting a copyrighted work without the owner's permission. Zacchini suggests that the scope of copyright protection will not be narrowed by the fact that the copyrighted work is projected over the public airwaves. For the above reasons the justification for extending the implied consent theory to memorialization is lacking. The limited scope of first amendment restrictions on copyright, the limited scope of the fairness doctrine, the Alaska Television case and the Zacchini case lead to the conclusion that the right to convert broadcast signals into sights and sounds does not include the right to memorialize those sights and sounds.

These developments in the right of public performance suggest two conflicting arguments in the Betamax litigation. On the one hand, Congress' revival of the distinction between activity that economically impinges upon the value of a copyright and activity that does not in the CATV area supports a conclusion that use of Betamax infringes the plaintiff's copyrights. Moreover, the implied consent-public interest argument to the contrary is unpersuasive. On the other hand, the de minimus violation approach of Aiken strongly suggests that home use of Betamax is not an infringing act. This suggestion is strengthened by recent development of a

115. 97 S.Ct. 2849 (1977).

116. Id. at 2857 (emphasis added). 
"home use" exception from infringement for the recordation of sound recordings.

\section{DeVelopments In Liability for Copying Phonograph ReCords: HOME USE AS COMPARED TO FAIR USE}

Although Congress groups videotape recordings with motion pictures in the new Act, ${ }^{117}$ the close analogy between tape recording records and tape recording television shows ${ }^{118}$ renders comparison of liability for tape recording records appropriate in considering liability for using Betamax.

Prior to the passage of the Sound Recording Act of $1971,{ }^{119}$ phonograph records were not copyrightable ${ }^{120}$ and the copyrights in musical compositions embodied in records were not violated if the bootleg copier ${ }^{121}$ paid royalties pursuant to the compulsory license system. ${ }^{122}$ These restrictions on copyright stemmed, on the one hand, from a Supreme Court definition of copy that required visual comprehensibility ${ }^{123}$ and, on the other hand, from a well-grounded fear that a monopoly in the manufacture of records would develop. ${ }^{124}$

\section{A. The Sound Recording Act and Home Use.}

Congress passed the Sound Recording Act to undercut the privileged position of record and tape pirates, ${ }^{125}$ who would purchase an album, record copies of it, pay the compulsory license fees, and undersell the legitimate record manufacturer who had to pay the musicians and the technicians for the creation of the sound recording. The concern was that the reproducer

117. 17 U.S.C.A. $\$ 101$ (West 1977):

'Audiovisual works' are works that consist of a series of related images which are intrinsically intended to be shown by the use of machines or devices such as projectors, viewers, or electronic equipment, together with accompanying sounds, if any, regardless of the nature of the material objects, such as films or tapes, in which the works are embodied .... '[M]otion pictures' are audiovisual works.

118. See notes 199-207 infra and accompanying text.

119. Pub. L. No. 92-140, § 1(a), 85 Stat. 391 (codified at 17 U.S.C. § 1(f) (Supp. V 1975)).

120. E.g., Capitol Records, Inc. v. Mercury Records, Corp., 221 F.2d 657 (2d Cir. 1955).

121. Although the cases which relied on Aeolian Co. v. Royal Music Roll Co., 196 F. 926 (W.D.N.Y. 1912) as discussed in text accompanying notes 129-33 infra, held that recording a record (as opposed to hiring a band and having it play the tune which is then recorded) will not bring the recorder within the compulsory license provisions, it was widely thought that sound pirates would be so immunized. H.R. REP. No. 487 at 2; see Nimmer, Photocopying and Record Piracy: Of Dred Scott and Alice in Wonderland, 22 U.C.L.A.L. REV. 1052 (1975).

122. 17 U.S.C. $\& 11(\mathrm{e})(1970)$ (old act) provides, generally, that if the owner of copyrighted music permits it to be recorded on a record, anyone can make "similar use" of the music upon the paying of two cents royalty per song per record to the copyright owner.

123. White-Smith Music Pub. Co. v. Apollo Co., 209 U.S. 1 (1908).

124. H.R. REP. No. 487 at 6; Second Supplementary Report, c.9 at 4.

125. H.R. REP. No. 487 at 2. 
could exploit a sound recording without contributing to its creation. ${ }^{126}$ Section $1(f)$ gave to the manufacturers of sound recordings copyright protection against duplicate recordings that are fixed after February 15, 1972.127 This limited copyrightability of sound recordings, which includes the right to duplicate the sound recording, to prepare a derivative work (but only to the extent that the actual sounds embodied in the sound recording are rearranged), and to distribute the phonorecords to the public by sale, lease, rental or loan, is continued in section 114 of the new Act.

Sound recordings fixed prior to 1972 are not copyrightable. ${ }^{128} \mathrm{How}$ ever, copyright owners of such musical compositions are not left helpless in the event that a tape pirate records their songs. A long dormant case, Aeolian Co. v. Royal Music Roll Co. ${ }^{129}$ has been revived by the courts to allow musical copyright owners to sue for infringement if a tape pirate duplicates a record and attempts to tender the compulsory licensee fee. In Aeolian, a record company sued a competitor for infringement of section 1(c), alleging that defendant duplicated Aeolian's records. Since the defendant in that case did copy plaintiff's record and subsequently tendered to the copyright owner the compulsory license royalty, the question remaining was whether defendant, by copying plaintiff's record, was making a "similar use of the copyrighted work," which would enable defendant to bring himself within the operation of the compulsory license, section $1(\mathrm{e})$. The court held that similar use does not include exact duplication of the prior record.

The provision of the statute (Section 1(e)) that "any other person may make similar use of the copyrighted work" becomes automatically

126. "The pirating of records and tapes is not only depriving legitimate manufacturers of substantial income, but of equal importance is denying performing artists and musicians of royalties and contributions to pensions and welfare funds . . . . Id. Applying the doctrines of unfair competition or misappropriation, several state courts have enjoined record pirates. See, e.g. , Capital Records, Inc. v. Erickson, 2 Cal. App. 3d 526, 82 Cal. Rptr. 798, cert. denied, 398 U.S. 960 (1970); Capital Records, Inc. v. Spies, 130 I1l. App. 2d 429, 264 N.E.2d 874 (1970); NBC, Inc. v. Nance, 506 S.W.2d 483 (Mo. Ct. App. 1974); CBS, Inc. v. Melody Recording Co., 124 N.J. Super. 322, 306 A.2d 493 (Sup. Ct. 1973); Capital Records Inc. v. Greatest Records, Inc., 43 Misc. 2d 878, 252 N.Y.S.2d 553 (Sup. Ct. 1964); Liberty/VA, Inc. v. Eastern Tape Corp., 11 N.C. App. 20, 180 S.E.2d 414, cert. denied and appeal dismissed, 278 N.C. 702, 181 S.E.2d 600 (1971); CBS, Inc. v. Custom Recording Co., 258 S.C. 465, 189 S.E.2d 305, cert. denied, 409 U.S. 1007 (1972); Mercury Record Productions v. Economic Consultants, Inc., 64 Wis. 2d 163, 218 N.W.2d 705 (1974), cert. denied and appeal dismissed, 420 U.S. 914 (1975).

127. The section has survived constitutional challenge on the ground of vagueness, United States v. Taxe, 540 F.2d 961 (9th Cir. 1976), cert. denied, 429 U.S. 1040 (1977), and violation of due process, United States v. Bodin, 375 F. Supp. 1265, 1268 (W.D. Okla. 1974). For examples of criminal convictions for record piracy under the amendment, see United States v. Maliconte, 531 F.2d 439 (10th Cir. 1975) and United States v. Blanton, 531 F.2d 442 (10th Cir. 1975).

128. 17 U.S.C. § 1(f) (Supp. V 1977); see 17 U.S.C.A. § 115(a)(1) (West 1977) (new act).

129. 196 F. 926 (W.D.N.Y. 1912); see also Standard Music Roll Co. v. F.A. Mills, Inc, 241 F. 360 (3d Cir. 1917). 
operative by the grant of the license; but the subsequent user does not thereby secure the right to copy the . . . records. He cannot avail himself of the skill and labor of the original manufacturer of the . . . record by copying or duplicating the same, but must resort to the copyrighted composition or sheet music, and not pirate the work of a competitor . . . 130

Therefore, the bootlegger was an infringer, not a licensee.

The holding in Aeolian, that a pirate who duplicates a licensed sound recording is liable for infringement because duplication of a record is not "similar use" of the copyrighted work, was first brought back to life in the wake of the Sound Recording Act of 1971 in Duchess Music Corp. v. Stern. ${ }^{131}$ The decision in Duchess, which allows for both civil and criminal actions against tape pirates duplicating sound recordings fixed both before and after 1972, is based on an analysis similar to that in Aeolian and has gained rapid acceptance among courts, ${ }^{132}$ if not among commentators. ${ }^{133}$ Section 115 of the new Act codifies the basis for liability in Duchess; ${ }^{134}$ thus, both the record manufacturer and the composer may hold copyrights that are infringed by duplication of a sound recording, and the federal government may pursue criminal sanctions if the recording is done willfully and for profit. ${ }^{135}$

In spite of this case law, the legislative history of the 1971 Act indicates that home recording of a copyrighted record may not be an infringement. In its report on the Sound Recording Act of 1971, the House Committee on the Judiciary wrote:

Specifically, it is not the intention of the Committee to restrain the home recording, from broadcasts or from tapes or records, of recorded per-

130. $196 \mathrm{~F}$. at 927. The court also held, mistakenly, that the owner of the musical copyright could transfer to the licensee record manufacturer the copyright owner's exclusive right to manufacture records. Thus, the record manufacturer was the plaintiff, not the musical copyright owner.

131. 458 F.2d 1305 (9th Cir.), cert. denied, 409 U.S. 847 (1972).

132. See, e.g., Fame Pub. Co. v. Alabama Custom Tape, Inc., 507 F.2d 667 (5th Cir.), cert. denied, 423 U.S. 841 (1975); Jondora Music Pub. Co. v. Melody Recordings, Inc., 506 F.2d 392 (3d Cir.), cert. denied, 421 U.S. 1012 (1975); Edward B. Marks Music Corp. v. Colorado Magnetics, Inc., 497 F.2d 285 (10th Cir. 1974), cert. denied, 419 U.S. 1120 (1975); Heilman v. Bell, 434 F. Supp. 564 (E.D. Wis. 1977); International Tape Dist., Ltd. v. Levi, 188 U.S.P.Q. 539 (D.D.C. 1975); E-C Tapes, Inc. v. Kelly, 412 F. Supp. 245 (N.D. Ill. 1975); Fame Pub. Co. v. S \& S Distributors, Inc., 363 F. Supp. 984 (N.D. Ala. 1973).

133. M. NIMMER, supra note 19, at $\S 108.4621$; Nimmer, Photocopying and Record Piracy, supra note 121; see Commission on Revision of the Federal Court System, Recommendations for Change, Appendix B, reprinted at 67 F.R.D. 281, 294-95 (1975).

134. 17 U.S.C.A. $\$ 115(\mathrm{a})(1)$ (West 1977). The House Report states: "[A] person is not entitled to a compulsory license of copyrighted musical works for the purpose of making an unauthorized duplication of a musical sound recording . . . " H.R. REP. No. 1476 at 108; see Second Supplementary Report, c.9 at 37.

135. 17 U.S.C. $\$ 104$ (1970); 17 U.S.C.A. $\$ 506$ (West 1977) (new act). 
formances, where the home recording is for private use and with no purpose of reproducing or otherwise capitalizing commercially on it. This practice is common and unrestrained today, and the record producers and performers would be in no different position from that of the owners of copyright in recorded musical compositions over the past 20 years. ${ }^{136}$

It has been argued that since the Judiciary Committee, in light of Duchess, "misconstrued" the prior state of the law as to the availability of a remedy for owners of copyright in recorded musical compositions, the "home use exception" to infringement should be rejected. ${ }^{137}$ This argument misses the mark. As suggested above, the courts in Duchess and its progeny acted in the era of the Sound Recording Amendment of 1971, and it seems likely that the courts were subtly influenced by the new congressional attitude toward record piracy. Furthermore, even if Congress did misconstrue prior law, that is entirely beside the point. The Judiciary Committee was indicating Congress' intent in enacting new law; ${ }^{138}$ the scope of the new law was suggested by a comparison to the old law. That the comparison was not true because of a misconception of the state of the old law does not affect the scope of the new law. The misconception is still available for comparison.

136. H.R. REP. No. 487 at 7 (emphasis added). The sole purpose of the sound recording amendment was to make "record piracy," which combines duplication with commercial exploitation, illegal. During the Senate's deliberation on the amendment, Senator McClellan said:

The recent rapid increase in the unauthorized commercial duplication of legitimate recordings has become a serious problem both in this country and abroad. The widespread availability of inexpensive equipment has encouraged extensive commercial pirating of recordings and tapes .... By granting a limited copyright in sound recordings this legislation will make a major contribution to the suppression of this unethical and unfair business competition.

117 CONG. REC. 12763 (1971).

Mr. Kastenmeier responded to questions from the floor:

Mr. Kazen: Am I correct in assuming that the bill protects copyrighted material that is duplicated for commercial purposes only?

Mr. Kastenmeier: Yes.

Mr. Kazen: In other words, if your child were to record off of a program which comes through the air on the radio or television, and then used it for her own personal pleasure, for listening pleasure, this use would not be included under the penalties of this bill?

Mr. Kastenmeier: This is not included in the bill . . . On page 7 of the report, under 'Home Recordings,' Members will note that under the bill the same practice which prevails today is called for; namely, this is considered both presently and under the proposed law to be fair use. The child does not do this for commercial purposes. This is made clear in the report.

117 CONG. REC. $34748-49$ (1971) (emphases added). See also 117 CONG. REC. 34748 (remarks of Rep. Kastenmeier), 34749 (remarks of Rep. Railsback) (1971); Pre-Trial Memorandum for Defendant at 9-25.

137. Pre-Trial Memorandum for Plaintiff at 64-67.

138. See, e.g., 117 CoNG. REC. 12764 (1971) (remarks of Senator Hart): "Its purpose is to prevent record 'piracy,' both the illegal form of piracy, . . . and legal piracy, where all statutory liabilities are met." 
Still, there is no home recording exception on the face of section 1(f). ${ }^{139}$ Nor does the new Act contain an explicit exception for home recording, as it does for limited duplication of copyrighted materials by libraries and archives in section 107.140 Nonetheless, two courts have adopted-one by dicta, one by implication-the "home use exception."

The Supreme Court in Goldstein v. California ${ }^{141}$ rejected a claim that federal copyright law preempted a California record piracy statute. In its discussion of the workings of the copyright clause, the court said in dicta: "An author who possesses an unlimited copyright may preclude others from copying his creation for commercial purposes without permission. In other words, to encourage people to devote themselves to intellectual and artistic creation, Congress may guarantee to authors and inventors a reward in the form of control over the sale and commercial use of copies of their works." 142 The Court seems to be suggesting that the presence or absence of commercial purposes is vital in determining infringement. Whether this is true as to infringement per se is doubtful for the simple reason that the statutes do not make commercial purpose an explicit element of infringement. ${ }^{143}$ But as noted above, the congressional intent (with which the Court seems to be agreeing in this record piracy case) concerning liability for the recording of records, off the air, and audio tapes (and, by analogy, audiovisual tapes) requires that commercial purpose be considered. ${ }^{144}$

In Electra Records v. Gem Electronic Distributors, Inc. ${ }^{145} \mathrm{Gem}$ Electronics installed "Make-A-Tape" machines in its record stores. The machine was capable of reproducing on a blank tape an entire recorded tape in two minutes. Gem would sell blank tapes to a customer, who would select a tape from an inventory which the store kept for that purpose, deposit fifty cents into the "Make-A-Tape" machine and record the store's tape. Electra's copyrighted sound recordings were among those loaned from the store's "library." The court granted plaintiff's motion for a preliminary injunction. Relying in part on an unreported decision from the Southern

139. Professor Nimmer suggests that this means there is no home use exception. $M$. NIMMER, supra note 19, at $\$ 109.212$. However, it seems clear that legislative intent can prevail over the actual language used in a statute. See Sorrells v. United States, 287 U.S. 435,447 (1932).

140. With respect to the use of copyrighted materials for nonprofit purposes, the bill in the judgment of the committee provides a careful structure [sic] balance between the legitimate rights of the creators, and the reasonable needs of users. Particular attention has been given to the concerns of classroom teachers and public libraries.

122 Cong. ReC. 1545 (daily ed. Feb. 6, 1976) (remarks of Sen. McClellan).

141. 412 U.S. 546 (1973).

142. Id. at 555; see also Gilliam v. ABC, Inc., 538 F.2d 14, 24 (2d Cir. 1976).

143. See Wihtol v. Crow, 309 F.2d 777 (8th Cir. 1962).

144. The rationale for this consideration is discussed in notes 160-63 infra.

145. 360 F. Supp. 821 (E.D.N.Y. 1973). 
District of Ohio, ${ }^{146}$ the court rejected Gem's attempt to distinguish its actions from ordinary tape piracy by arguing that the duplication was individual rather than en masse and that the customers, not Gem, did the actual recording. ${ }^{147} \mathrm{Gem}$ tried to analogize the use of its "Make-A-Tape" machine to that of a photocopy machine in a library or to a home recording, to which Congress "clearly did not intend to extend coverage of the bill "148

The court implicitly recognized the home recording exception as a defense to copyright infringement by making a principled argument why it should not apply to the facts before the court. ${ }^{149}$ The theoretical underpinning of the home use exception is suggested by the court's reasons for rejecting the tendered analogies. Gem's recordings and library photocopying were dissimilar because: (1) photocopies usually duplicate only a portion of the book, compared to the recording of entire tapes; (2) time and expense discourage photographing entire books, while "Make-A-Tape" makes it easy and inexpensive to duplicate; (3) photocopies are inferior and less desirable than the original, while the new tapes were as good as the old; and (4) Gem was commercially motivated, while the librarians are not. ${ }^{150}$ The home use analogy was rejected because of Gem's commercial exploitation and because Gem's actions constituted "mass piracy on a custom basis." 151

\section{B. Home Use: Refracted Fair Use.}

1. Traditional fair use. The reasons given by the Electra court for rejecting the photocopy analogy are based on more or less orthodox "fair use" grounds; the home use analogy was not an orthodox fair use argument. Fair use ${ }^{152}$ is an equitable rule of reason that classifies some copying as "permitted copying of copyrighted material." 153 Beyond this unhelpful designation, it is "so flexible as virtually to defy definition." 154 According

146. CBS, Inc. v. Commercial Music Service Co., Civil Action 73-134 (S.D. Ohio, May 8, 1973).

147. 360 F. Supp. at 824 .

148. Id.

149. In lending the copyrighted sound recording to the customers without charge, in selling the less costly blank tape from which the spurious but exact copy may be made, and in providing the equipment whereby it may be speedily done at minimal cost, defendants are engaging in mass piracy on a custom basis. To view this activity as a form of 'homerecording' would stretch imagination to the snapping point.

Id. at 824-25.

150. Id. at 824 .

151. Id. at 824-25 (emphasis added).

152. A detailed discussion of fair use is beyond the scope of this Comment. It is examined only as general background in the analysis of home use.

153. Needham, supra note 32 , at 79.

154. Time, Inc. v. Bernard Geis Assoc., 293 F. Supp. 130, 144 (S.D.N.Y. 1968); see H.R. REP. No. 1476 at 66. 
to Nimmer, the central question in applying fair use is whether the copying will tend to detrimentally affect the marketability of the copyright owner's work-essentially whether the copy will serve the same function as the original. ${ }^{155}$ Nonetheless, a common approach to fair use is to consider several factors pertaining to its applicability. ${ }^{156}$ According to the recent legislative recognition of fair use in section 107 of the new Act, the most significant factors are:

(1) the purpose and character of the use, including whether such use is of a commercial nature or is for nonprofit educational purposes;

(2) the nature of the copyrighted work;

(3) the amount and substantiality of the portion used in relation to the copyrighted work as a whole; and

(4) the effect of the use upon the potential market for or value of the copyrighted work.

The traditional approach to fair use, although it articulates a list of factors to be considered, emphasizes the final factor-detrimental impact on the value of the property in copyright. ${ }^{157}$ Using this approach, one has little difficulty in concluding that home use is not fair use. ${ }^{158}$ The cumulative impact of all home uses will result in decreased profitability of reruns. The copying is of the entire work. The nature of the work is not scientific or scholarly. Indeed, the factors listed by the court in the Electra case in concluding that "Make-A-Tape" was not analogous to library photocopying would also distinguish home use from the library photocopying: while the lack of commercial motivation is common to both the home use and the library photocopying, home use of a Betamax could make a good quality recording of the entire copyrighted work at relatively little expense.

2. An alternative view of fair use. The peculiar legislative genesis of home use and its character as a de minimus violation, require that one examine all and not just one of the multiple factors of fair use. ${ }^{159}$ Extrapola-

155. M. NIMMER, supra note 19 , at $\S 145$, at $646-47$; see Meeropol v. Nizer, 560 F.2d 1061, 1070 (2d Cir. 1977), cert. denied, 98 S. Ct. 727 (1978); Wainwright Sec., Inc. v. Wall St. Transcript Corp., 558 F.2d 91, 96 (2d Cir. 1977), cert. denied, 98 S. Ct. 730 (1978).

156. See, e.g., Schulman, Fair Use and the Revision of the Copyright Act, 53 IowA L. Rev. 832 (1968); Needham, supra note 32, at 80-95.

157. U.S. Copyright OfFice, Report of the Register of Copyrights on the GeNeral Revision of the U.S. Copyright Law, 87th Cong., 1st Sess. 24-25 (House Comm. Print 1961); Holland, The Audiovisual Package: Handle With Care, 22 Bull. CR. Soc. 104, 123 (1974).

158. M. NimMER, supra note 19, at § 109.212; Holland, supra note 157, at 124-25; Meyer, supra note 10 , at $37-38$.

159. It is clear the Congress did not feel bound to any particular concept of fair use: "The bill endorses the purpose and general scope of the judicial doctrine of fair use, but there is no disposition to freeze the doctrine in the statute, especially during a period of rapid technological change . . . . [T] he courts must be free to adapt the doctrine to particular situations." H.R. REP. No. 1476 at 66 . 
tion from the legislative history suggests a five factor test for home use: (1) whether the recording was commercially motivated; (2) whether the recording, in itself, impairs the value of the copyright; (3) whether there are multiple recordings; (4) whether recording was for personal use or pleasure; and (5) whether the method of recording was no more sophisticated than ordinary home equipment.

The traditional focus on the cumulative economic impact of Betamax ignores a significant legislative clarification of the "first test" of orthodox fair use: the purpose and character of the use. Earlier legislative formulations of the factors of fair use referred simply to "the nature and the character of the use." 160 The House Committee on the Judiciary added the extra words in "an express recognition that, as under present law, the commercial or non-profit character of an activity, while not conclusive with respect to fair use, can and should be weighed along with other factors in fair use decisions."161 The commercial motive aspect of fair use is accorded too little weight under the traditional approach; ${ }^{162}$ to use the traditional

A recent utilization of the multiple factor test is found in Encyclopaedia Britannica Ed. Corp. v.Crooks, No. 77-560 (W.D.N.Y. Feb. 27, 1978). Defendant was a non-profit corporation providing educational services to public schools in Erie County, New York. One of the services was making audiovisual tapes from televised educational films and distributing copies of the master copy to teachers from over 100 schools on request. Plaintiffs owned copyrights in several of the copied films. In its copying service, defendant used equipment worth one-half million dollars, employed a staff of five to eight full-time persons, and made as many as 10,000 tapes for distribution per year. The court granted plaintiff's motion for a preliminary injunction because defendant's videocopying "would seem to constitute a blatant violation" of plaintiff's copyrights and because, on the basis of evidence then available, defendant's use was not "fair." Although defendant's "purpose and character" of the use was educational and not commercially motivated, the other three factors of fair use dominated. The court had to presume irreparable injury; evidence suggested that defendant's videocopying did injure plaintiff's market for educational films. Defendant copied entire films and recopied them as many time as requested. The copying was not occasional or informal. Defendant engaged in "a highly organized and systematic program for reproducing videotapes on a massive scale." Consequently, the court concluded that the substantiality of the copying and the detrimental impact were sufficient to deny the applicability of fair use.

160. S. REP. No. 473, 94th Cong., 1st Sess. 5 (1975); see Holland, supra note 157, at 123; Meyer, supra note 10, at 37.

161. H.R. REP. No. 1476 at 66; accord, Second Supplementary Report, c.2 at 28 ("although the commercial or nonprofit character of a use is not necessarily conclusive with respect to fair use, in combination with other factors it can and should weigh heavily in fair use decisions").

162. Authorities recognizing the role of commercial motive include: Wainwright Sec. Inc. v. Wall St. Transcript Corp., 558 F.2d 91, 96-97 (2d Cir. 1977) (dicta), cert. denied, 98 S. Ct. 730 (1978); Encyclopaedia Britannica Ed. Corp. v. Crooks, No. 77-560 (W.D.N.Y. Feb. 17, 1978); Loew's Inc. v. CBS, Inc., 131 F. Supp. 165, 176 (S.D. Cal. 1955), aff'd sub nom. Benny v. Loew's Inc., 239 F.2d 532 (9th Cir. 1956), aff'd by an equally divided court sub nom. CBS, Inc. v. Loew's Inc., 356 U.S. 43 (1958); Conde Nast Publications v. Vogue School of Fashion Modeling, 105 F. Supp. 325, 333 (S.D.N.Y. 1952); Henry Holt \& Co. v. Liggett \& Meyers Tobacco Co., 23 F. Supp. 302, 304 (E.D. Pa. 1938); see Time, Inc. v. Bernard Geis Assoc., 293 F. Supp. 130, 146 (S.D.N.Y. 1968); Needham, supra note 32, at 86, 90, 92-93; Yankwich, What 
approach in a situation where the non-commercial motive plays an important role appears anomalous. ${ }^{163}$ Home use of a Betamax meets this commercial motive test.

Moreover, this congressional highlighting of commercial motive in the fair use equation, when coupled with the expression of congressional intent to exempt home recording of copyrighted sound recordings from infringement liability, ${ }^{164}$ requires a reformulation of the scope of the fourth factor: economic impact on the copyright. The reformulation appears necessary because the traditional test measures the cumulative economic impact on the property in copyright ${ }^{165}$ by asking whether the copies tend to replace the copyrighted work. ${ }^{166}$ Under this approach, copying on machines capable of reproducing the entire copyrighted work for personal use constitutes infringement because of the cumulative impact of all such uses. This result is clearly not intended by Congress in creating the home use exemption. The alteration of the economic impact factor necessary to harmonize it with Congress' intent narrows the perspective of economic impact from the

is Fair Use?, 22 U. CHI. L. REv. 203, 209 (1954). Contra, Rosemont Enter., Inc. v. Random House, Inc., 366 F.2d 303, 307 (2d Cir. 1966), cert. denied, 385 U.S. 1009 (1964); see Wihtol v. Crow, 309 F.2d 777 (8th Cir. 1962); Mills Music, Inc. v. Arizona, 187 U.S.P.Q. (BNA) 22 (D. Ariz. 1975); Chappell \& Co. v. Costa, 45 F. Supp. 554 (S.D.N.Y. 1942).

163. The cases that reject commercial motive as an element of fair use fall into one of two groups. First, some cases hold that the total copying of a work for any purpose cannot be a fair use. Wihtol v. Crow, 309 F.2d 777, 780 (8th Cir. 1962); Robert Stigwood Gp., Ltd. v. O'Reilly, 346 F. Supp. 376, 384-85 (D. Conn. 1972). The rationale of these cases is questionable in light of Williams \& Wilkins Co. v. United States, 487 F.2d 1345 (Ct. Cl. 1973), aff'd by an equally divided court, 420 U.S. 376 (1975), where the Court of Claims held that the photocopying of entire articles in medical journals for use of researchers was fair use. Id. at 1362. "There is, in short, no inflexible rule excluding an entire copyrighted work from the area of "fair use." " Id. at 1353. The holding clearly indicates that copying an entire work does not preclude fair use. See Comment, supra note 21, at 102. But see Encyclopaedia Britannica Ed. Corp. v. Crooks, No. 77-560 (W.D.N.Y. Feb. 27, 1978). The court's analysis in Williams \& Wilkins has been rather severely criticized, see, e.g., M. NIMMER, supra note 19 , at $\$ 145$. The second group of cases apply fair use despite the existence of commercial motive. Rosemont Enter., Inc., v. Random House, Inc., 366 F.2d 303, 307 (2d Cir. 1966), cert. denied, 385 U.S. 1009 (1967); Berlin v. E-C Publications, Inc., 329 F.2d 541 (2d Cir.), cert. denied, 379 U.S. 822 (1964). This application of fair use does not contradict the consideration of commercial motive, but merely points out that the absence of commercial motive is not a necessary condition for operation of the doctrine. Cases failing to recognize commercial motives in fair use perhaps make the unjustified deduction that since intent to infringe is irrelevant, M. NIMMER, supra note 19, at $\$$ 148 , all intent is irrelevant, see, e.g., Chappell \& Co. v. Costa, 45 F. Supp. 554 (S.D.N.Y. 1942). At any rate, they fail to accord significance to a factor that obviously relates directly to the commercial incentive rationale of copyright law. See H.R. REP. No. 2222, 60th Cong., 2d Sess. 7 (1908).

164. See note 136 supra and accompanying text.

165. S. REP. No. 473 , supra note 160 , at 65 ; M. NIMMER, supra note 19 , at $\$ 146$, at 646 .

166. Wainwright Sec. Co. Inc. v. Wall St. Transcript Corp., 558 F.2d 91, 96 (2d Cir. 1977) cert. denied, 98 S. Ct. 730 (1978); Berlin v. E-C Publications, 329 F.2d 541, 545 (2d Cir.), cert. denied, 379 U.S. 822 (1964). 
cumulative to the individual impact upon the copyright. ${ }^{167}$ The inquiry, then, is whether the individual's copying has an inappreciable economic impact upon the value of the copyright. ${ }^{168}$

This narrowing of perspective is buttressed by two previously discussed developments. First, examination of individual impact is suggested by the de minimus violation theory in Aiken and the codification of that result in the new Act. ${ }^{169}$ Both Aiken and section $110(5)$ permit public performance of the copyrighted material provided that it is done in a small commercial establishment with home equipment. The result of removing liability in such a situation is a significant reduction in the value of the copyright; the necessity for obtaining performance licenses disappears in thousands of instances. In addition, the Aiken theory of practical unenforceability makes the most sense when understood to connote insignificance of individual impact. ${ }^{170}$ Second, the reasoning in the Electra decision suggests the necessity of associating individual economic impact with commercial motive in the home use context. The court distinguished "Make-A-Tape" from home use for two reasons: because Gem had a commercial motive and because such copying constituted "mass piracy on a custom basis." 171 The mass piracy holding would appear to permit the

167. See Needham, supra note 32. Although it is not entirely clear from reading Needham, his definition of "de minimis" appears to be the one adopted here. Considering an individual impact would not render the factor meaningless. See Encylcopaedia Britannica Ed. Corp. v. Crooks, No. 77-560 (W.D.N.Y. Feb. 27, 1978) (corporation made up to 10,000 audiovisual copies per year).

168. See cases cited in note 175 infra. In enacting the new copyright act, Congress intended to "avoid exhausting the constitutional power of Congress to legislate in this field . . . . H.R. REP. No. 1476 at 51. Instead of subordinating all other interests to the promotion of arts and sciences, Congress has sought to create a delicate balance between the interests promoted and the interests impinged. Compare this approach with the one finally adopted in congressional efforts to ease the Great Depression of the 1930's. In Wickard v. Filburn, 317 U.S. 111 (1942), the Court, recognizing the necessarily broad scope of the Agricultural Adjustment Act of 1938 (AAA), 7 U.S.C: $\S \S 1281-1393$ (1976), found that wheat grown for home consumption was within congressional regulatory authority under the commerce clause. The AAA had the clear intent of buffering domestic wheat prices in the United States from the extreme fluctuation of prices resulting from surpluses and shortages. 317 U.S. at 115, 126. For the individual home consumer, the principle of de minimus use was not allowed. Congress was going as far as it could under the commerce clause. The 1976 Copyright Act does not appear to go as far as the AAA did.

169. See notes 54-67 supra and accompanying text.

170. See notes 69-70 supra and accompanying text.

171. $360 \mathrm{~F}$. Supp. at 825 . It should be remembered that Gem argued that the presence of "Make-A-Tape" machines in its stores was dissimilar from the operation of the run-of-the-mill tape pirate because the duplication was accomplished individually and was actually performed by the customers, not by Gem. See note 147 supra and accompanying text. If the court had accepted this argument, Gem's position would have been wholly analogous to Sony's position of merely providing individuals the capacity to record. However, the court rejected this argument. The effect of Gem's operation was identical to the effect of an ordinary tape pirate: the public was able to purchase tape recordings at a low price because payments of copyright 
inverse of mass recording-singular recordings. ${ }^{172}$ However, if the orthodox economic impact approach were utilized, even the singular recording in the home without commercial intent would not constitute fair use because such recording, when considered as a class, would still have a detrimental impact upon the value of the copyright. Therefore, the individual approach to economic impact seems to be an unstated premise of the Electra court's recognition of the home use defense.

The home use exception differs from orthodox "fair use" also in restricting the amount of copying done. It is possible to have fair use and large amounts of copying, ${ }^{173}$ but the "mass piracy" holding in Electra precludes the idea of grand scale copying under the home use exception. Thus, the House Committee on the Judiciary suggests a bar on multiple copies by requiring that a home use have "no purpose of reproducing or otherwise commercially capitalizing on it." 174 The use must be "such, and such only, as will not cause substantial injury to the . . . [copyright owner]." 175 And, to narrow the permissible uses even further, the use must not be multiple duplication of the copyrighted work. This approach does not focus on whether the copies or the copy are used for the same purpose, but on whether a single copy ${ }^{176}$ of a copyrighted work can be said to cause injury to the copyrighted work. ${ }^{177}$

A fourth test of home use is whether the recording is done for personal use. This test is the logical corollary to the commercial motivation require-

royalties or performers' fees were not made. The only difference, then, between Gem and the ordinary tape pirate was that Gem had to keep a much smaller inventory of tape recordings than the ordinary pirate in order to satisfy customer demands. To hold that Gem was not a tape pirate in such circumstances would be to exalt form over substance.

Of course, labeling Gem a pirate does not require labeling Sony a pirate. Although Sony is certainly commercially motivated, the effect of its actions is to sell to the public both the blank tapes and the machines to use them on. It is not possible to say in Sony's situation-as it must be said in Gem's situation-that Sony is the constructive copier of the copyrighted programs.

172. See notes 173-77 infra and accompanying text.

173. See Williams \& Wilkins Co. v. United States, 487 F.2d 1345 (Ct. Cl. 1973). But see Encyclopaedia Britannica Ed. Corp. v. Crooks, No. 77-560 (W.D.N.Y. Feb. 27, 1978).

174. H.R. REP. No. 487 at 7 (emphasis added).

175. Lawrence v. Dana, 15 F. Cas. 26, 61 (C.C.D. Mass. 1869) (No. 8,136); accord, Ginn \& Co. v. Apollo Pub. Co., 215 F. 772, 778 (E.D. Pa. 1914); Hill v. Whalen \& Martell, Inc., 220 F. 359, 360 (S.D.N.Y. 1914); see Runge v. Lee, 441 F.2d 579, 581 (9th Cir. 1971).

176. See generally Leon v. Pacific Tel. \& Tel. Co., 9l F.2d 484, 486 (9th Cir. 1937), where the court states that "wholesale" (for example, multiple) copying cannot be fair use.

177. "Isolated instances of minor infringements, when multiplied many times, become in the aggregate a major inroad on copyright that must be prevented." S. REP. No. 473, supra note 160 , at 65 . The impact of this statement is modified by the context in which it is made. The discussion centered on the economic impingement factor and its interrelation with the other factors. It was prefaced by the remark: "With certain special exceptions (use in parodies or as evidence in court proceedings might be examples) a use that supplants any part of the normal market for a copyrighted work would ordinarily be considered infringement." The argument here, of course, is that home use is such an exception. 
ment and to the Aiken de minimus analysis. Moreover, this requirement appears in the case law to a limited extent. ${ }^{178}$ The Court of Claims in Williams \& Wilkins distinguished commercial uses and the making of a single copy for individual, personal or restricted use. ${ }^{179}$ If the purpose of the copying is personal use, the copying is "fair" - even if of an entire article. ${ }^{180}$ Legislative history also provides some support for this requirement. In the legislative history of the Sound Recording Act of 1971, copying for personal use and pleasure meshed with the very concept of home use. ${ }^{181}$ However, in its discussion of the permissibility of recording educational television broadcasts off-the-air by educational institutions, the Senate Committee on the Judiciary posited that such institutional recording could never be motivated by mere convenience and still constitute fair use. ${ }^{182}$ These differing legislative expressions appear irreconcilable. The question is, then, which context is more analogous to the Betamax situationindividual home audio tape recording or institutional audiovisual tape recording ? $^{183}$ By anticipating home audio-visual recording, the Register of Copyrights provides the answer. "New technical devices will probably make it practical in the future to reproduce televised motion pictures in the home. We do not believe the private use of such a reproduction can or should be precluded by copyright." 184

A fifth factor-that the recording equipment is at an ordinary, home level of sophistication-derives, sensibly, from the difference between home recording and piracy. It receives further justification from the devel-

178. Prior to Williams \& Wilkins, the case law apparently had not touched on the subject of private or personal use. W. NASRI, CRISIS IN COPYRIGHT 31 (1976); U.S. COPYRIGHT OFFICE, Copyright Law Revision: Studies Prepared for the Subcomm. on Patents, Trademarks, AND Copyrights of THE CoMm. OF THE Judiciary, UNited States SENATE, Study 14, 86th Cong., 2d Sess. 11 (Comm. Print 1960). However, in the context of scholarly copying of copyrighted materials, several commentators have asserted that private use is not an infringing use. Cohen, Fair Use in the Law of Copyright, in 6 ASCAP COPYRIGHT SYMP. No. 6 at 43,58 (1955); Shaw, Publication and Distribution of Scientific Literature, 17 C. \& RESEARCH LIB. 293, 301 (1956).

179. 487 F.2d at 1353 n. 12.

180. See id. at 1350, 1353; cf. Scherr v. Universal Match Corp., 417 F.2d 497, 503 (2d Cir. 1969), cert. denied, 397 U.S. 936 (1970) (Friendly, J., dissenting) (there should be no relief granted for technical infringements done purely for the infringer's own pleasure); Fritch, supra note 19, at 117-18, 37 S. CAL. L. REv. at 235 (courts will be loathe to reach the harsh result of foreclosing private taping off-the-air for noncommercial purposes).

181. See note 136 supra.

182. S. REP. No. 473 , supra note 160 , at 66 .

183. See text accompanying notes 199-207 infra.

184. U.S. CopyriGHT OFFICE, supra note 157, at 30 (emphasis added). See also U.S. CopYRIGHT OFFICE, supra note 178, STUDY 16 at $117 \& 118$, where the author considered it conceivable that a court would use fair use to hold that a purely private exhibition of a motion picture would not violate the right of performance and where he labeled the extension of the right of performance to private exhibitions a "questionable restraint." 
opments in the right of public performance. The Supreme Court, through its decisions in Teleprompter, Fortnightly and Aiken, evolved a definition of "performance" that permitted all sorts of activities to be classified as noninfringing. In response to Fortnightly and Teleprompter, Congress cut back allowable "performance" along lines following economic impingement. In response to Aiken, Congress ignored the significant detrimental economic impact upon the copyrights caused by removing the capacity to license the small commercial establishment for public performance. ${ }^{185}$ Congress recognized a judicially-created exception to the right to perform by providing that unsophisticated performances in a small commercial establishment would not be considered infringement. ${ }^{186}$ The outer limit of the congressionally recognized de minimus violation was a small commercial establishment using a home receiver and four ordinary speakers. ${ }^{187}$ Except for the commercial nature of the performance, which would be excluded by the non-commercial motive factor, ${ }^{188}$ the facts and holding of Aiken, especially the emphasis on ordinary home equipment, are fully applicable to the home use situation.

3. Possible objections to a home use exception. There are several arguments against recognizing a home use exception and against applying it to audiovisual recording. First, the basic difference between civil and criminal infringement is that criminal infringement requires willful infringement for the purpose of commercial advantage or private financial gain while civil infringement does not. ${ }^{189}$ If home use exempts some not-forprofit copying, it appears to reduce the scope of civil infringement to that of criminal infringement: commercially motivated copying. But home use does not destroy the statutory distinction between the scope of civil and criminal

185. See text accompanying note 170 supra.

186. 17 U.S.C.A. $\$ 110(5)$ (West 1977) (new act). The rationale of the exemption as articulated by the Register of Copyrights is:

[T]o make clear that it is not an infringement of copyright merely to turn on, in a public place, an ordinary radio or television receiving apparatus of a type commonly sold to members of the public for private use. This exception would apply for the most part to the incidental entertainment of small public audiences (patrons in a bar, customers getting a shoeshine, patients waiting in a doctor's office, etc.). It is not intended to exempt larger establishments, such as supermarkets, bus stations, factories, etc., in which broadcasts are not merely received in the usual manner of a private reception, but are transmitted to substantial audiences by means of a receiving system connected with a number of loudspeakers spread over a wide area. The exemption would also not apply in any case where the public is charged directly to see or hear the broadcast.

Second Supplementary Report, c. 4 at 5 (quoting from a 1965 Report of the Register concerning a prior legislative formulation of the exemption).

187. H.R. REP. No. 1476 at 87. Compare Encyclopaedia Britannica Ed. Corp. v. Crooks, No. 77-560 (W.D.N.Y. Feb. 10, 1978) (equipment worth one-half million dollars).

188. See notes $136,160-63$ supra and accompanying text.

189. Compare 17 U.S.C.A. § 50I(a) (West 1977) (civil infringements, new act) with 17 U.S.C. § 104 (1970) (criminal infringement, old act) and 17 U.S.C.A. § 506(a) (West 1977) (criminal infringement, new act). 
infringement. Not all nonprofit copying can claim the home use exemption; such copying must also meet the other four criteria. Thus, nonprofit civil infringements are conceivable. Furthermore, the central distinction between home use and criminal infringement is that criminal infringement requires willfulness, which is irrelevant to home and fair use. In Conde Nast Publications v. Vogue School of Fashion Modelling, Inc. ${ }^{190}$ an action was brought for unfair use of a trade name and for infringement of copyright. Defendant's name was 'inspired" by Conde Nast's Vogue magazine. One of the alleged copyright infringements involved defendant's use of reproductions of the front covers of Vogue magazines on defendant's promotional literature. Defendant did not realize that the magazine covers were copyrighted, yet the court concluded there was a civil infringement. "Although the defendants may have lacked the intention to deliberately infringe, the purpose of the copying was to promote their business . . . . This is exactly the prohibition which limits the privilege granted by the 'fair use' theory . . . "191 Here, then, is a situation where there can be neither criminal infringement nor applicational home use. In short, the scope of criminal and civil infringement remains distinct.

Second, it could be urged that the new law, in both its legislative history and its explicit language, provides no support for a continuation of the home recording exception created in the Sound Recording Act of 1971. Indeed, the legislative history pertaining to section 114 (exclusive rights in sound recordings) is cursory. ${ }^{192}$ In all probability, this reflects a recognition that section 114 closely tracks section 1(f) of the old Act. The Register of Copyrights, after noting that the Sound Recording Act of 1971 had been enacted in response to "the extraordinary explosion of tape piracy," and that it had been made permanent in 1974, implied that tape piracy was not an issue considered in the passing of the revision act in $1976 .{ }^{193}$ The reason for enacting the 1974 amendment ${ }^{194}$ making the Sound Recording Act permanent, according to the House Committee on the Judiciary, was the unlikelihood that a Senate general revision bill (which contained, in material aspects, section 114 of the new act) ${ }^{195}$ would pass the House. ${ }^{196}$ The general bill would provide the same protection to sound recording as afforded by making section $1(f)$ permanent. Congress considered it necessary to make

190. 105 F. Supp. 325 (S.D.N.Y. 1952).

191. Id. at 333.

192. H.R. REP. No. 1476 at 106-07; S. REP. No. 473 , supra note 160 , at 87-88.

193. Second Supplementary Report, c.8 at 9-10.

194. Pub. L. No. 93-573, § 101, 88 Stat. 1873 (codified at note to 17 U.S.C. $\$ 1$ (Supp. V 1975)).

195. S. REP. No. 1035, 93d Cong., 2d Sess. 16 (1974). The Senate version also included a compulsory license provision for public performance of sound recordings. Id. at 17 .

196. H.R. REP. No. 1389, 93d Cong., 2d Sess. 2 (1974). 
section 1(f) permanent because a lapse would trigger an increase in piracy. Thus, "[t]he perpetration of protection without lapse cannot await enactment of the revision bill." 197 Because section 114 of the new Act essentially tracks section 1(f) of the old Act, the legislative history of section 1(f) is equally applicable to the new Act. Consequently, the home use exception explicated in the legislative history of the Sound Recording Act of 1971 (and implicit in the definition of "piracy") is equally applicable to at least the sound recording provisons of the new Act. ${ }^{198}$

The most serious doubts as to the applicability of the home use exception to a home user of Betamax are raised by questioning the analogy between audio tape recording and audiovisual recording. Section 101 of the new Act associated audiovisual recording with motion picures, ${ }^{199}$ as distinguished from phonorecords, which are material objects in which sounds, perceivable directly or with a machine (other than sound accompanying an audiovisual work) are fixed. By definition, then, an audiovisual tape is a motion picture; an audio tape is a phonorecord. The authorities agree that audiovisual tapes should be classified with motion pictures. ${ }^{200}$ The definition makes a difference: the limitations on the exclusive rights of copyrighted motion pictures, section 102(6), are not nearly as thorough as those on section $102(7)$ sound recordings. ${ }^{201}$

Making an audiovisual tape of a television show and making an audio tape are definitionally different acts. Yet several similarities suggest the appropriateness of associating the two. First, the exclusive right to reproduce sound recordings is limited to the sounds already fixed in an existing sound recording and does not extend to the right to make sound recordings of the same song in another version. ${ }^{202}$ Beyond this and the express limitations on sound recordings, ${ }^{203}$ the copyright in sound recordings is just as exclusive as that in audiovisual works. It is within this area of exclusivity that the equitable doctrines of fair and home use operate. ${ }^{204}$ It is from the exclusive right to record sound recordings that home use exempts audio tape recorders. "Exclusive" can mean no more for audiovisual works than for sound recordings, and the Register of Copyrights has expressed concern for

197. Id. at 4 .

198. It could be argued that the specific statutory exemptions in section 108 for certain copying done in libraries and elsewhere provides, by negative implication, that home use not be an exemption. However, home use is an aspect of fair use, and the provisions in 108 and other express limitations do not affect the scope of fair use. S. REP. No. 473, supra note 160, at 67.

199. See note 117 supra.

200. See, e.g., M. Nimmer, supra note 19 , at $\S 116$.

201. Compare 17 U.S.C.A. $\S \S 114-115$ (West 1977) (new act) with id. \$§ 111 \& 112.

202. See notes 122-28 supra and accompanying text.

203. See note 201 supra.

204. Cambridge Research institute, Omnibus Copyright Revision Comparative ANALYSIS OF THE ISSUES 35 (1973). 
protecting users of home audiovisual equipment similar to that expressed by Congress for home users of audio equipment. ${ }^{205}$ It is just as much an infringement to duplicate a copyrighted phonorecord ${ }^{206}$ as it is to make a copy of a movie. ${ }^{207}$ Further, there is no difference between the acts necessary to copy records and motion pictures. In both instances, the person purchases the recording machine and attaches it to another device in his home-a television, a phonograph or a radio receiver. He uses magnetic tapes to memorialize all or part of a television or radio broadcast or the contents of a recording. His intent is the same; his acts are the same; the result is the same-a magnetic tape copy that can be played at his pleasure. There may be a definitional difference between making a copy of a movie on an audiovisual recorder and making a copy of a sound recording on an audio recorder, yet there is no difference in fact.

\section{CONCLUSION}

Under general principles of infringement and under the traditional application of the fair use doctrine, Sony and the home user appear to infringe Universal's and Walt Disney's copyrights. The congressional response to the CATV decisions also suggests this conclusion. However, a refracted form of fair use-home use-has sufficient grounding in legislative history and case law to suggest a different result. This new form of fair use is adapted to avoid the enormous implications of holding home copiers liable for infringement. It is dictated by congressional recognition of a distinction between commercially motivated recording and de minimus home recording and looks to the effect of the individual's recording on the value of the copyright rather than the class effect. It is further supported by the de minimus rationale of Aiken. For these reasons it should be concluded that home use of Betamax does not infringe copyrights. While the congressional response to the CATV cases and the inappropriateness of traditional fair use in this context suggest the opposite conclusion, it cannot be doubted that Betamax use fits the several criteria of the new home use exception. ${ }^{208}$

205. See note 184 supra and accompanying text.

206. United States v. Taxe, 540 F.2d 961 (8th Cir. 1976), cert. denied, 429 U.S. 1040 (1977).

207. Rohauser v. Friedman, 306 F.2d 933 (9th Cir. 1962); Cardinal Films, Inc. v. Republic Pictures Corp., 148 F. Supp. 156, 158 (S.D.N.Y. 1957).

208. According to Defendant's Pre-Trial Memorandum at 65 , the individual user of Betamax recorded 20 minutes of "Never Give An Inch," a motion picture copyrighted by Universal. He has played the recording once so that his family could see it. On these facts, the vidiot's use clearly falls within the scope of home use. 